\title{
Assessment of the level of some physico-chemical parameters and heavy metals of Rebu river in oromia region, Ethiopia
}

\begin{abstract}
The present study has undertaken to assess the water quality as well potential source of contamination of Rebu River by considering effluent discharged from soap and detergent factory. In the study, three sampling sites along the river course have chosen based on the objectives of the study and potential source of pollution. Composite sampling technique has used to collect the water samples and analyzed for some physic-chemical parameters and heavy metals using HACH's Spectrophotometer and FAAS by following standard laboratory procedure. The instruments have calibrated using de-ionized water and standard solution by following standard procedures. The water quality was relatively acceptable at upstream (site A) of the river while both the physic chemical and heavy metals at sites B and $\mathrm{C}$ became impaired, an inference that might suggested a significant pollution from soap and detergent effluents and municipal discharges. Site B (effluent discharge site) recorded high values in E.C. $(1592.6 \mu \mathrm{S} / \mathrm{cm})$, TDS $(2359.5 \mathrm{mg} / \mathrm{L})$, turbidity $(800 \mathrm{mg} / \mathrm{L})$, salinity $(2440 \mathrm{mg} / \mathrm{L}), \mathrm{NO}_{3}^{-}(324.5 \mathrm{mg} / \mathrm{L}), \mathrm{PO}_{4}^{3-}(163.3 \mathrm{mg} / \mathrm{L}) \mathrm{NH}_{3}(15.8 \mathrm{mg} / \mathrm{L}), \mathrm{Fe}(2.02 \mathrm{mg} / \mathrm{L}), \mathrm{Pb}$ $(0.16 \mathrm{mg} / \mathrm{L}), \mathrm{Na}(1557.6 \mathrm{mg} / \mathrm{L})$ and $\mathrm{K}(22.3 \mathrm{mg} / \mathrm{L})$. These results however implicated site B to be the most polluted site, probably being the point of discharge. Fluoride ion was the only parameter that did not detected. A comparison of the measured parameters with the national and international standards set by EDWQ (2010) and WHO (2008) shows that all the parameters measured (except $\mathrm{NO}_{2}^{-}, \mathrm{SO}_{4}{ }^{2-a n d ~} \mathrm{Cu}$ ) were above the standards. This indicates that the river water was significantly contaminated and therefore not suitable for domestic, agricultural and industrial uses. The concentrations of each parameter (except Fe) among the selected sites were significantly different (ANOVA, $p \leq 0.05$ ). The findings indicate that, there is a need to protect the quality of the river system. Therefore, it recommended that the government and other responsible authorities have to take appropriate corrective action and should support further study has to be conducted on other physical, chemical and untested biological parameters of significant health concern and identification of potential source of the contaminants of the river
\end{abstract}

Keywords: Rebu River, water quality, heavy metals, FAAS, water pollution, assessment
Volume 3 Issue 3 - 2018

\author{
Mekonnen Tadesse,' Dereje Tsegaye,' Gosa \\ Girma $^{2}$ \\ 'Department of Chemistry, Adama Science and Technology \\ University, Adama, Ethiopia. \\ ${ }^{2}$ Department of Biology, Stream of Natural Science, Asella \\ College, Asella, Ethiopia
}

Correspondence: Gosa Girma, Department of Biology, Stream of Natural Science, Asella College, Asella, Ethiopia, Email gosagirma74@gmail.com

Received: July 02, 2018 | Published: August 14, 2018
Abbreviations: ANOVA, analysis of variance; APHA, american public health association; CCME, Canadian council of ministers for environment; COD, chemical oxygen demand; DO, dissolved oxygen; EC, electrical conductivity; EDWQ, Ethiopian drinking water quality; EMA, Ethiopian mapping agency; ICMR, Indian council of medical research; ISO, international standard organization; SD, standard deviation; SPADNS, sodium 2-(para sulphonate)-1, 8-dihydoxy-3, 6-naphthalene disulphonate; SPSS, statistical package for the social science; TDS, total dissolved solid; US-EPA, united state environmental protection agency; WHO, world health organization

\section{Introduction}

\section{Background}

Water is the most abundant substance on the earth's surface that is essential for the survival of all known forms of life. Next to air we breathe, water is humankind most important substance. ${ }^{1}$ It is always the vital commodity for humans, used for drinking, cooking, agriculture, transport and recreation, among other purposes. Nevertheless, most important is the fact that water is a major constituent of all living matter, comprising up to two-thirds of the human body. In addition, water plays an important role in the world economy, as it functions as a solvent for a wide variety of chemical substances, industrial cooling and transportation. It also serves as a receptor of industrial waste, domestic waste and wastewater resulting from other uses of water. ${ }^{2}$

Water obtained from two principal natural sources: Surface water such as fresh water, lakes, rivers, streams, etc. and ground water such as borehole water and well water. ${ }^{3}$ Rivers are vital and vulnerable freshwater systems across the world, providing main water resources for domestic, industrial, and agricultural purposes. They are open dynamic ecosystems whose physical, chemical and biotic characteristics can greatly influenced by anthropogenic activities taking place within their drainage basins. Urban centers put huge amount of organic and synthetic waste in to rivers with little or no treatment. With-ever increasing population and industrialization, however, human societies affect rivers and their ecosystem structure and function in an ever-alarming way. In general, the effect of human activities in rivers and their ecosystem affect one or more of the five attributes of watersheds and streams; Water quality, habitat structure, stream flow patterns, sources of energy and nutrients, and biotic interaction. ${ }^{4}$ 
Today, a number of rivers and streams flow-through urbanized areas across the world, were profoundly impact by changes associated with urbanization. ${ }^{5}$ Continuous economic growth, urbanization and high human population growth rate are some of the contributors to the rapid increase in volume and variety of both industrial and household waste generated in many rapidly growing urban centers, especially in developing countries. ${ }^{6}$ In Ethiopia, the dominant source of drinking water used to supply major urban and rural communities is from river, wells and springs. Although there are no systematic and comprehensive assessment programs on the equality of the water in the country, there are increasing indications of water contamination problems in some parts of the country. ${ }^{7}$ The major causes of this contamination could be soil erosion, domestic waste from urban and rural areas, agricultural activities, industrial wastes, inadequate treatment, and over-use of limited water resources. ${ }^{7,8}$

Direct discharge of foreign material from different sources to river and open lands, leakage of industrial wastes from poorly designed septic tank to the ground, water discharge of effluents without detoxifying the waste solid/liquid from domestic municipal, organic matter of plant and animal origin are among few sources of pollution that change the water quality in the country. All the industries growth without care for impact on water resources eventually made much of the water across the countries especially in urban center, unfit for aesthetic value, recreational purpose, for agricultural and domestic drinking water. ${ }^{9}$ A number of studies have indicated that among industries located in the Ethiopia, 90 to 96 percent discharge their waste without any form of treatment to nearby water bodies and open spaces..$^{10}$ Many researchers' have been conducted an analysis to evaluate the quality of river water in the country. Their results have compared with different national and international water quality standards such as EPA, USEPA, and WHO. However, because of rapid urbanization, industrialization, old agricultural practice, over uses of chemicals, etc. our rivers are still at high risk. This study examines the water quality parameters and heavy metals content of Rebu River in relation to EDWQ and WHO guidelines for surface water. It also aimed at on the assessment of level of pollution and potential source of contaminants of the river water under the consideration of effluents from soap and detergent factory in the area under the study.

\section{Statement of the problem}

Rebu River is one of the largest rivers found around Woliso town As the river runs along the side of the town (at the South eastern part), it could be fed with contaminants brought by run-off from the upload into the river at the peak of the floods, discharge from municipal wastes, and industrial wastes from soap and detergent factory. At the effluent discharge site, the water is highly colored, turbid and the vegetation's along the river appears scorched despite the fact that water from this river is the major source in the area. Since there is no municipal water supply for the local communities living around the river, they rely on this untreated river water for drinking, irrigation and other household purposes. The environment damage caused by water pollution from municipal discharge and industrial (soap and detergent) effluent in Rebu River has not studied yet. These create an urgent need to assess the level of pollution of the river through the consideration of the impact of effluents from the soap and detergent factory and municipal discharge on water quality of the river (Fig 1).

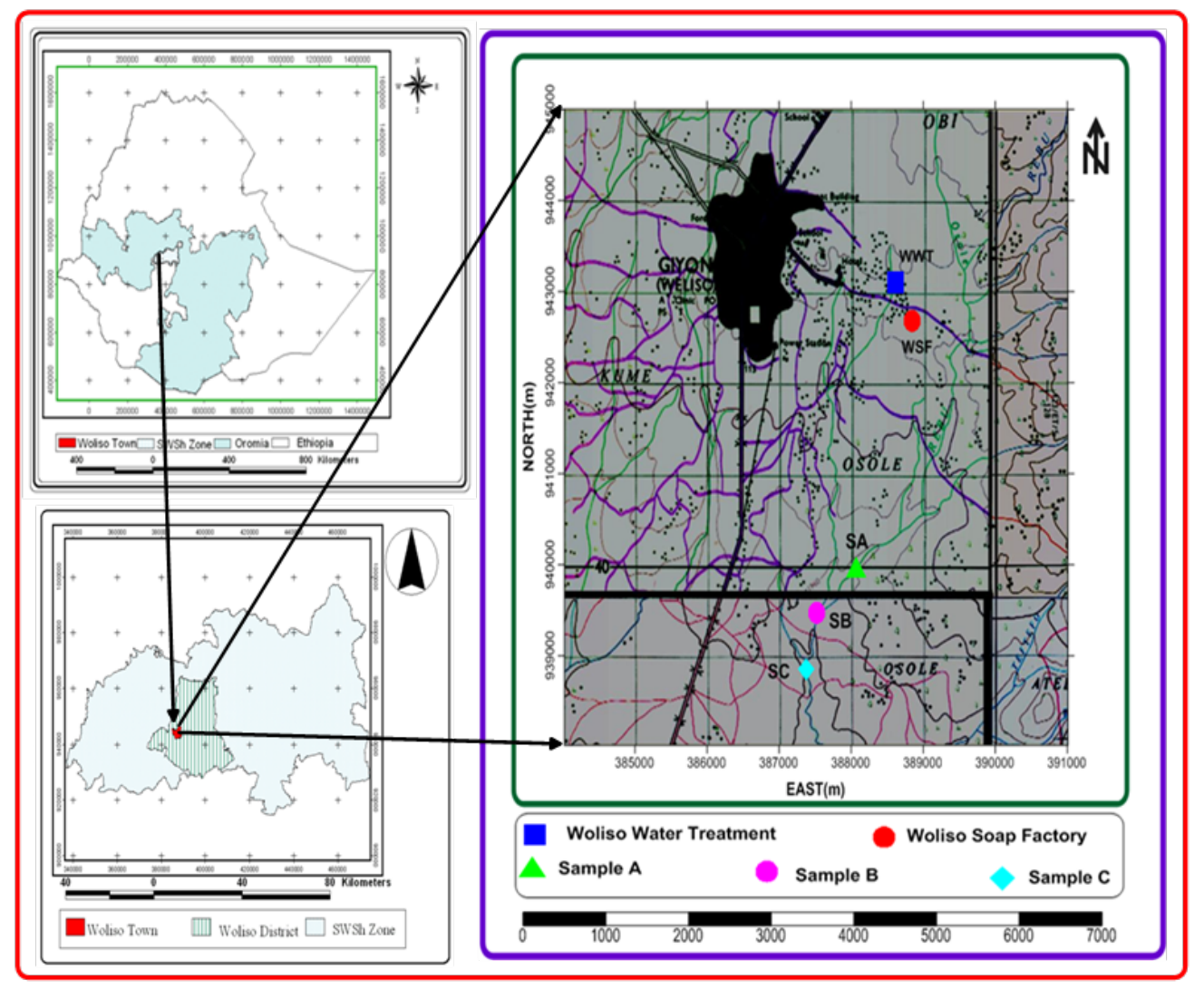

Figure I Map of Ethiopia showing the three sites of study area around Woliso (developed from GPS and EMA, 2005). 


\section{Significance of the study}

The significances of this study are

1. To provide adequate information on the distribution of heavy metals in Rebu River so that it will ensure the health of individuals who uses this river

2. Help the Woreda water and sewerage office to identify source of the water pollution problem in order to use the surface water for domestic purposes.

3. Help the Woreda's water, irrigation and energy office as base line information on the quality of the river water under study to use the river for irrigation purpose.

4. Hoped to be the result of this study will assist the relevant industries and authorities in designing appropriate preventive measure to ensure that the water quality in the river is improved.

5. Provide a baseline data for any environmental analyst who intended to carry out further investigation.

\section{Objectives of the study}

General objective: The main objective of this study is to assess the level of contamination of Rebu River by determining the concentration of some physico-chemical parameters and heavy metals by considering the effluent discharged from the Soap and Detergent Factory.

\section{Specific objectives}

1. To determine the concentration of heavy metals ( $\mathrm{Fe}, \mathrm{Zn}, \mathrm{Pb}, \mathrm{Cu}$ and $\mathrm{Mn}$ ), $\mathrm{Na}, \mathrm{K}$ and physic-chemical parameters ( $\mathrm{pH}$, temperature, color, salinity, turbidity, conductivity, total dissolved solid, $\mathrm{NO}_{2}$, $\mathrm{NO}_{3}^{-}, \mathrm{SO}_{4}^{2-}, \mathrm{PO}_{4}^{3-}, \mathrm{F}^{-}$and $\mathrm{NH}_{3}$ ).

2. To compare each measured parameters of the river water, with the national (EDWQ, 2010) and international 59(WHO, 2008) ${ }^{11}$ surface water guideline to identify the degree of pollution or impact of the effluent discharged from soap and detergent factory to the river.

3. To compare the variation of different parameters among the selected sites of the river

4. To comment on the effect due to the presence of one or more of the physico-chemical parameters and heavy metals on human health and environment in general.

5. Provide further baseline data for proper management and sustainable utilization of the river water.

\section{Review of literature}

\section{Sources of heavy metals in river water}

The two main sources of heavy metals in water and wastewater are natural and anthropogenic. Naturally, heavy metal pollutants enter into river water through ore-bearing rocks, wind-blow dust, forest fires and vegetation. In addition, urban run offs and aerosol particles are natural source of heavy metals of water bodies. It has reported that volcanic eruptions produce hazardous impacts to the environment, climate and health of exposed individuals. Apart from the deterioration of social and chemical conditions and the gases released, various organic compounds as well as heavy metals have released during eruptions. Soil erosion has indicated to be a natural source of heavy metal pollution in water. The two main agents of soil erosion are wind and water. During rainfall, sediment-bound heavy metals have distributed to the soil. Water containing agrochemicals with toxic metal concentration drop this sediment bound metal in the soil even as it causes erosion. ${ }^{12}$

Some of the anthropogenic sources of heavy metals in water and wastewater effluents are industrial discharge, domestic sewage, urban storm, non-point source runoff and atmospheric precipitation, landfills, inputs from rural areas. In addition, metal finishing and electroplating, mining and extraction operations are also included in anthropogenic sources of heavy metals. In some cases, textile industries have indicated to be major sources of heavy metal pollutants in water. This has said to be mostly originate from the dyeing process, which is a major process in such industries. The compounds used for these dyeing processes (coloration) include copper, chromium, nickel and lead which is very toxic and carcinogenic..$^{13}$ Although heavy metals are naturally present in small quantities in all river water, it is almost exclusively through human activities that these levels have increased to toxic levels. The heavy metals, therefore, find their way into natural water bodies originated from both natural and anthropogenic sources, which accumulate in the media and subsequently enter the human bodies.

\section{Industrial effluents discharged to river}

Industrial effluents are the major source of pollution of water and air in the environment. Depending on the industry and their water use, various levels of pollutants have discharged in to the aquatic environment directly or indirectly through public sewer line. Wastewaters are generated by many industries because of their operation and processing. The waste water discharged from the industries contain suspended solids, both degradable and nonbiodegradable organics, oils and greases, heavy metal ions, dissolved inorganic, acids, bases and coloring compounds which have capability to pollute nearby rivers. ${ }^{14}$

The impact of industrial toxic and hazardous wastes on the aquatic life including microorganism cannot be over-stressed. Consequently, up on the industrial revolution, many production and manufacturing companies have due to improper waste management techniques, added toxic and hazardous wastes including synthetic compounds into the aquatic environment. Despite a variety of alternatives available for industrial waste management, many industries continue to degrade the most precious but scarce natural resources especially water. Industrial effluents have characterized by their abnormal turbidity, conductivity, chemical oxygen demand (COD), total suspended solids (TSS) and total hardness. The river residential environment in any industrial effluent site is always under considerable stress due to the prevailing harsh environment conditions, especially high temperature and salinity, restricted benthic fauna diversity and over all development of a fragile intertidal ecosystem. ${ }^{14}$ Most of the rivers in the urban areas of the developing countries are the ends of effluents discharged from the industries. African and Asian countries experiencing rapid industrial growth and this are making environmental conservation a difficult task..$^{15}$ One of the three people in developing countries does not access to safe drinking water and some 123 fresh water animal species have gone to extinction in North America. ${ }^{16}$ A number of industries 
in developing countries still use outdate or the least practicable technologies due to economic constrain. Majority of the industries in Ethiopia are old and use out dated technology. Despite the fact that their number is few, their impact in terms of pollution is enormous. Moreover, a great majority of these industries discharges their waste in the form of liquid, dust particles and smoke without treatment. ${ }^{17}$

\section{Soap and detergent industry}

Soap, from a chemical standpoint, is a salt (or a mixture of salts) of fatty acids. As with all salts, soap contains a positive ion, usually $\mathrm{Na}^{-}$ or $\mathrm{K}^{+}$, a negative ion, usually the anions of long chained carboxylic acids obtained by the hydrolysis of animal fats or vegetable oils. Synthetic detergents replaced soap powders for home laundering in the late 1940s, because the carboxylate ions of the soap react with the calcium and magnesium ions in the natural hard water to form insoluble materials called lime soap. Some commercial laundries that have soft water continue to use soap powders. Metallic soaps are alkali-earth or heavy metal long-chain carboxylates, which are insoluble in water but soluble in no aqueous solvents. They have used as additives in lubricating oils, greases, rust inhibitors, and jellied fuels. Detergents are cleaning products derived from synthetic organic chemicals. Surfactants are mainly responsible for the cleaning action of detergents. The other components include bleach, filter, foam stabilizer, builders, perfume, soil-suspending agents, enzymes, dyes, optical brighteners and other materials designed to enhance the cleaning action of the surfactant. ${ }^{18}$ Alkyl sulphonates (AS) are anionic surfactants widely used in household and personal cleansing application. At a concentration about $106 \mu \mathrm{g} / \mathrm{L}$, it is toxic to aquatic animals. ${ }^{19}$ However, industrial effluents from soap manufacturing industries have known to contain complex chemicals most of which are very toxic and capable of destroying the microbial habitats in a serious adverse way. For example, characterization of wastewater from soap processing plant indicated that the wastes are highly contaminated with organic compounds as indicated by COD and BOD values..$^{20}$ In a study to assess the seasonal variation in bacterial heavy metals biosorption in a receiving river Ezaima in Abia state as affected by industrial effluents. ${ }^{21}$ observed the overall seasonal variation of heavy metals such as lead, zinc and manganese in the rainy seasons. Moreover, effluent from the soap manufacturing plant contained significant concentrations of oil and grease amounting to $563 \mathrm{mg} / \mathrm{L} .{ }^{14}$ The inefficiency of waste treatment processes involved do not treat properly the waste being generate and thus the discharge effluents remain the source of water pollution in rivers in most developing countries like Ethiopia.

\section{Importance, sources and health effects of some heavy metals and physic-chemical parameters}

Some water pollutants have needed in trace amounts for plants and microorganisms as micronutrients, however, they become extremely toxic in high concentrations. Copper, iron, nickel, zinc, manganese, boron and phosphorus, for example, can be toxic or may otherwise adversely affect aquatic life when present above certain permissible limits. However, their presence in low amounts is essential to support and maintain functions in aquatic ecosystems. Other trace metals naturally, found in the body at low concentrations and are essential for human health. Iron, for example, prevents anemia, and zinc is a cofactor in over 100 enzyme reactions. However, some heavy metals such as cadmium, chromium, and lead have no known physiological activities, but they have proved detrimental beyond a certain limit.
In aquatic ecosystems, heavy metals greatly depress the number of living organisms. They have negative effect on the growth of aquatic organisms..$^{22}$

\section{Heavy metals}

The term heavy metal refers to any metallic chemical element that has relatively high density and is toxic or poisonous in at low concentration. The chief heavy metals note in environmental science includes Mercury (Hg), Cadimium (Cd), Arsenic (As), Chromium $(\mathrm{Cr})$, Thallium (TI) Lead $(\mathrm{Pb})$, Copper $(\mathrm{Cu})$, Manganese $(\mathrm{Mn})$, Zinc $(\mathrm{Zn})$, Nickel (Ni), --- etc. They are natural components of the earth crust. Compared to other types of water pollutants, heavy metals pollution is less visible, but their effects on the ecosystem and human beings can be intensive and very extensive. Thus, it has become a great concern in recent years because they are very harmful because of their non-biodegradable nature, long biological half-life and their potential to accumulate in different body parts of organism. They can be also concentrated along the food chain, producing their toxic effect at points after far removed from the source of pollution. ${ }^{23}$ Once liberated into the environment through air, drinking water, food, or countless human-made chemicals and products, heavy metals have taken into the body via inhalation, ingestion and skin absorption. Many heavy metals are carcinogenic, immunogenic, or mutagenic. They can affect cardiovascular system, reproductive and nervous system. Diseases like edema of eyelids, tumor, congestion of nasal mucous membrane and pharynx, stuffiness of head, gastrointestinal, muscular, reproductive, neurological and genetic malfunctions are caused by some of these heavy metals; cadmium, chromium, and lead. ${ }^{24}$ Although the potential detrimental effects of heavy metals polluted water on the quality of receiving water bodies are numerous, their risk effects may depend on the volume and composition of the effluent that has discharged. Intake of toxic metals can cause several harm to the body ranging from acute to chronic disease such as allergies, asthma, hypertension, anemia and immune system dysfunction. Aluminum, mercury and lead are known to attack the nerves and brain causing hyperactivity in children, liver and kidney dysfunction, Alzheimer's and other diseases in adult. ${ }^{25}$

\section{Physicochemical parameters}

Physico-chemical properties are parameters that do not identify particular chemical species but have used as an indicator of how water quality may affect water uses. ${ }^{26}$ Selection of parameters for testing of water quality is solely depends upon for what purpose we are going to use that water and what extent we need its quality and purity.

\section{Some related work to assess the water quality parameters and heavy metals}

Related works on some water quality indicators and heavy metals in different rivers due to excessive industries effluent, municipal discharge, and agricultural activities; and natural process have given in the following section:

Gupta et al., ${ }^{27}$ analyzed water samples from 20 sampling points of Kaital for their physic-chemical characteristics. Analysis for $\mathrm{pH}$, color, odor, hardness, chloride, alkalinity, TDS etc. on comparing the results against drinking water quality standards laid by Indian Council of Medical Research (ICMR) and World Health Organization, WHO, it is found that some of the water samples are non-potable for human being due to high concentration of one or the other parameter.

As shown in Amina ${ }^{28}$ water quality was determined in the different 
stretches of the river Sutlej sites (S1, S2, and S3) for a period of 1year (November 2006 to October 2007). SiteS1 was at Ropar Head Works; site S2 at upper stream of BudhaNallah at Phillaour, and site S3 was downstream of BudhaNallah in district Ludhiana (Punjab). Relatively low values of TDS, turbidity, BOD, total alkalinity, total hardness, chlorides, Nitrates, and phosphates have recorded at S1 and S2 as compared to $\mathrm{S} 3$. Heavy metals like $\mathrm{Pb}, \mathrm{Zn}, \mathrm{Cr}$, and $\mathrm{Ni}$ have detected at $\mathrm{S} 2$ and $\mathrm{S} 3$. The mean values of these parameters have compared with WHO and ICMR standards. This clearly indicated that the river water at sites $\mathrm{S} 2$ and $\mathrm{S} 3$ have found to be unsafe for human consumption. As cited in Amina, (2015), Akpan-Idiok et al. (2012) studied various physic-chemical parameters and some heavy metals for water quality assessment of Okpauku River for drinking and irrigation uses, in Nigeria. Using composite sampling method $\mathrm{pH}$, turbidity, EC, temperature, TDS; major cations $\left(\mathrm{Na}^{+}, \mathrm{K}^{+}, \mathrm{mg}^{2+}, \mathrm{Ca}^{2+}\right)$ as well as heavy metals using FAAS were determined. The study revealed that there was significant variation in the water quality parameters evaluated among the different location of Okpauku River. However, $\mathrm{pH}$, temperature, turbidity, Ammonia-Nitrogen, nutrient element, major ions, heavy metals were within the limits recommended by ${ }^{29}$ for drinking and irrigation purposes.

As indicated in review article carried by, ${ }^{30}$ different studies have conducted for testing the presence of heavy metals in the river Yamuna in Delhi of India. A research conducted by TERI (Yamuna, the poisoned river, 2012), showed moderate level of toxic metal at several locations. The study also emphasized on the effect of heavy metals on the vegetables growing on the riverbanks. As well as on the population dependent on the river, water. Extensive study of heavy metal contamination in water and soil has carried out in the Delhi segment of Yamuna basin where 13 sites have chosen. The key finding of this study was:

Heavy metals in the river water varies as $\mathrm{Fe}>\mathrm{Cr}>\mathrm{Mn}>\mathrm{Zn}>\mathrm{Pb}>$ $\mathrm{Cu}>\mathrm{Ni}>\mathrm{Hg}>\mathrm{As}>\mathrm{Cd}$; but, in the soil they varied as $\mathrm{Fe}>\mathrm{Mn}>$ $\mathrm{Zn}>\mathrm{Cr}>\mathrm{Pb}>\mathrm{Ni}>\mathrm{Hg}>\mathrm{Cu}>\mathrm{As}>\mathrm{Cd}$. Free ammonia levels 1.4-6.6mg/L was presents and were found to be unfit for propagation of wild life and fisheries.

Olatunji ${ }^{39}$ and Osibanjo ${ }^{31}$ reported that, the mean concentration of the measured heavy metals in the water sample from Niger River, North Central Nigeria, ranges from $\mathrm{Mn}(2.6-5.58 \mathrm{mg} / \mathrm{L}), \mathrm{Cu}(1.69-$ $3.57 \mathrm{mg} / \mathrm{L}), \mathrm{Zn}(1.65-3.25 \mathrm{mg} / \mathrm{L})$ and $\mathrm{Pb}(0.02-0.16 \mathrm{mg} / \mathrm{L})$. Under the same study, it has cited that, Kakulu and Osibanjo (1992) reported higher concentration of $\mathrm{Pb}, \mathrm{Cu}$ and $\mathrm{Zn}$ in water collected from Warri River and Calabar Rivers.

Adewoye, ${ }^{32}$ determined the physico-chemical and microbial status of Asa River, Nigeria where Soap and Detergent Factory discharges the effluent to the river. Water sample have obtained from three points of the river, point $\mathrm{A}$ (upstream), point $\mathrm{B}$ (effluent discharge point) and point $C$ (downstream) using composite sampling method. The results obtained in the analysis indicate that more bacteria have encountered at site $\mathrm{B}$, where detergent effluent has discharged into the river than both the upstream and downstream. The physic-chemical characteristic of the water samples has revealed the riches of site B in nitrate, phosphate and sulphate than other two sites, it can therefore be adduced that high microbial load obtained in site B might be unconnected with the abundance of nutrients. Thus, the effluent discharged at this site (point B) is capable of enhancing growth of microorganisms in the river. The highest bacterial and fungal isolates where found in point $\mathrm{B}$ and $\mathrm{C}$, this suggest that point $\mathrm{A}$ is exposed to non-site pollution particularly from agricultural, land and human wastes.

In another study, cited in, ${ }^{33}$ physic-chemical and bacteriological properties of water from dug well close to ASA River which run through industrial area in Ilorin, Kwara state of Nigeria has investigated; the water was colored and turbid with thin film oil present at the surface. The content of the TSS was very high making it unsafe for drinking. The high conductivity values suggested that dissolved solid are mostly mineral salts. Also all the water samples examined contained fecal coliform (E. coli) and high population of heterotrophic bacteria. This finding and/or the other indicated that the rush by developing countries to industrialize has resulted in the discharge of partially treated or raw wastes into the surrounding water bodies since the development of water treatment facilities has not kept pace with the rate at which the wastes have generated by the industries.

Water quality has affected when the rate of atmospheric deposition, storm water runoffs, domestic or industrial wastewater discharge, surpasses the carriage of capacity of water. ${ }^{23}$ It has reported that the differences in geography, geologies as well as activities in various rivers affect the amount of metals present (Bricker and Jones, 1995, cited in Olatunji, 2012). The availability and toxicity of chemical species of many heavy metals in aquatic environment has altered depending on the $\mathrm{pH}$ of water body.

The study carried by Aisien et al., (2003) in Nigeria-delta coast on river Ethiope shows that river Ethiope is highly contaminated with pollutants discharged on it from industries sited along its bank, sewage, market municipal solid waste, abattoir waste water and surface run - off. Many research studies have conducted in Nigeria, especially on those in Niger Delta coast because of the increasing river water pollution. The results obtained by researchers show that the effects of these effluents include high biological oxygen demand (BOD), dissolved and suspended solids, low dissolved oxygen (DO) and $\mathrm{pH}$ and the presence of inorganic elements. Besides, it has been reported that excessive contamination of river water will led to the following: Increased algae growth, resulting in eutrophication, reduced transparency and photosynthesis, thereby affecting the growth of fishes, aquatic plants and animals, death of fishes and production of offensive odors and color, increased turbidity, conductivity, temperature and heavy metals toxicity, increased microbial growth.

\section{Materials and methods}

\section{General description of sampling area}

\section{Location, Climate and topography of the town}

Woliso is one of the towns in Oromia regional state of Ethiopia, which has established in 1919 E.C. currently, the town is serving as a zonal town for the South West Shoa Zone and a seat for Woliso Woreda. According to 2007, G.C population census of Central Statistical Agency (CSA) report, the population size of Woliso town was 37,868 and now this number has projected to reach about 80,000 . Administratively the town has divided in to four Kebeles. The town has its own administrative structure that has led by a Mayor. ${ }^{34}$

The town is located at $8.31^{\circ} 60^{\prime \prime}$ North latitude and $37.58^{\circ} 60$ East longitudes. The elevation of the town ranges from 1900 to $20^{\circ} \mathrm{n}$ meters above sea level. The mean temperature of the town is $22.5^{\circ} \mathrm{C}$ and the mean annual rainfall is $1200 \mathrm{~mm} .{ }^{35}$ 
Woliso town is located at a distance of 114kilometers from the capital city of the country, Addis Ababa, along Addis Ababa to Jimma main road. Geographically, the boundaries of the town are Obi Koji (at the north), Fodu Gora (at the south), Leman Anchabi (at the east), and Badesa Koricha (at the west) Kebele Farmer Associations. Rivers like Ejersa, Walga, Kela, and Rebu, which are serving the local communities for domestic consumption and irrigation purpose, have found around the town. Currently, the town has two major factories named as Woliso Soap and Detergent Factory and Woliso Food Complex Factory with other Small Scale Industries. ${ }^{34}$

The study was conducted on Rebu River which is about $2.7 \mathrm{Km}$ far from the center of Woliso town. The river has originated from the highland, which is located at the eastern part of Woliso town, Oromia region, Ethiopia. Flowing Southwest direction of the plain of the town, the river is finally joined Gibe basin. Large quantities of untreated municipal sewage, agricultural chemicals and industrial effluents from the soap and detergent factory are directly discharged to tributary (locally named as Obi flood) flowing near the factory which finally joins the Rebu River. The main victims from this threat are the urban communities, which live near the factory and rural communities found in Leman Anchanbi and Fodu Gora Kebeles. Many villages at downstream of the river, uses the river water for domestic consumptions, drinking their cattle and widely used for irrigation purposes.

\section{Sampling sites selection}

A preliminary survey of sampling stations has done carefully for one day to select the appropriate sampling site based on the objectives of the study and potential sources of pollution. The sampling of water of the river has done for three consecutive months from January 2008 to March 2008. Three sampling sites, which cover a length of about $1.5 \mathrm{Kms}$ were selected by considering the relative sources of pollution to the river.

\section{Sampling site $\mathbf{A}$ (upstream)}

The site is located approximately $800 \mathrm{~m}(0.8 \mathrm{Km})$ upstream of the effluents discharge entry point from the soap and detergent factory into river. The land around the river is a farmland and partly covered with some indigenous trees and grasses.

\section{Sampling site B (effluents entry point)}

This site is located in the downstream of the first site at effluent entry point. The site is where effluents discharged from soap and detergent factory, domestic and sanitary waste materials of inhabitants of the community and municipal wastes mixed with Rebu River through small canals. In this site, the water surface appears slightly turbid during sampling time (Figure 2B). The land around the river has covered with grasses, eucalyptus trees and a farmland.

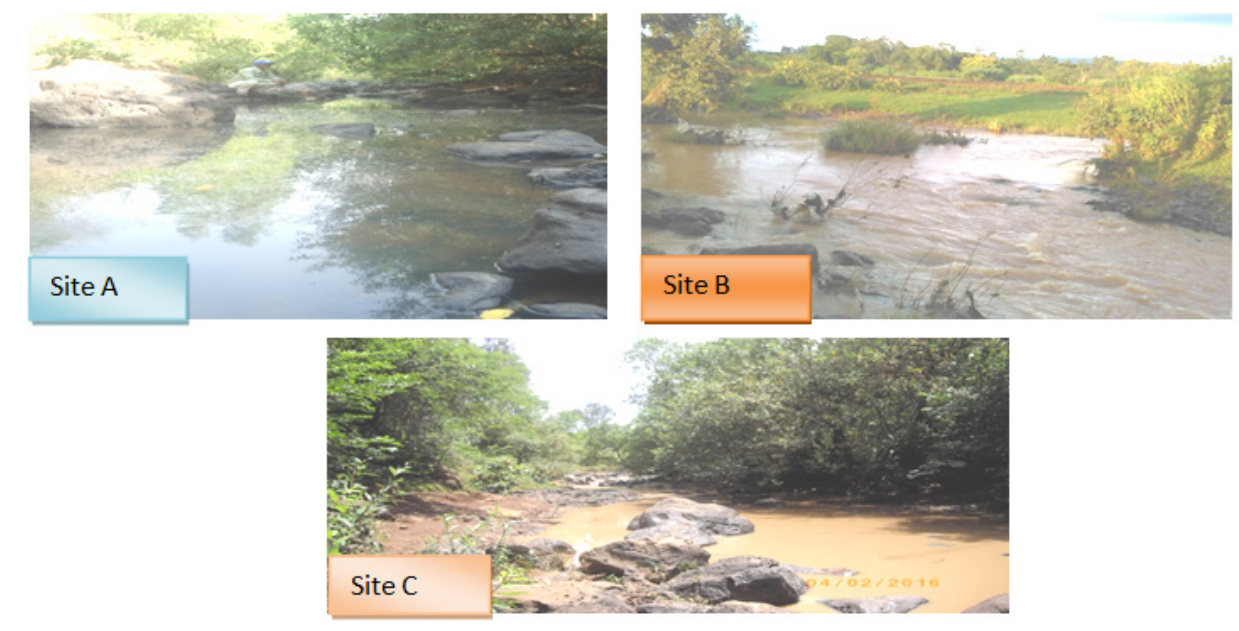

Figure 2 The three sampling sites of river water.

\section{Sampling site $\mathbf{C}$ (downstream)}

This site is located at about $700 \mathrm{~m}(0.7 \mathrm{Km})$ downstream from the discharge entry point (sample site B). The land around the river has covered with grasses, shrubs and eucalyptus trees. Agricultural activities are intense including river water abstraction for irrigation purpose. The land around the site is marshy.

\section{Materials and instruments}

Atomic Absorption Spectrometer (AAS) Model (ZEE nit 700p, Germany), Atomic Absorption Spectrometry (AAS) Model (AAS 220 Varian, Australia), Hot plate, Conical (Erlenmeyer) flask (125mL) or Griffin beakers $(150 \mathrm{~mL})$, Acid washed and rinsed with water,
Volumetric flask $(100 \mathrm{~mL})$, watch glass, glass fiber filter, funnel, filter paper, sucker, Spectrophotometer (Model DR 2800, Japan), Dropper, LDPE $(0.5-1.0 \mathrm{~mL})$, Light shield, Pipet, TenSette ${ }^{\circledR}(1$ to $10 \mathrm{~mL}$ ), Sample cells (1-inch square, $10 \mathrm{~mL}$ ), Stopper, Neopron \#2, solid, volumetric $(10 \mathrm{~mL})$, filler bulb, thermometer $\left(-10\right.$ to $\left.110^{\circ} \mathrm{C}\right)$, temperature Analyzer probe $\left({ }^{\circ} \mathrm{C}\right)$. Field Conductivity Meter Model (Elmetron, CC411), Portable Digital pH Meter, Portable Turbidimeter, Comparator and GPS, etrce (Thaila).

\section{Chemicals and reagents}

De-ionized water, $1000 \mathrm{mg} / \mathrm{L}$ in $2 \% \mathrm{HNO}_{3}$ stock solution of $(\mathrm{Cu}$, $\mathrm{Fe}, \mathrm{Zn}, \mathrm{Pb}, \mathrm{Mn}, \mathrm{Na}$ and $\mathrm{K}$ ) (BDH chemicals Ltd-UK) purchased from certified manufacturer, $69-72 \%$ nitric acid $\left(\mathrm{HNO}_{3}\right), 30 \%$ Hydrogen 
peroxide $\left(\mathrm{H}_{2} \mathrm{O}_{2}\right), 37 \%$ hydrochloric acid $(\mathrm{HCl}), \mathrm{La}\left(\mathrm{NO}_{3}\right)_{2}$, Reagent Powder Pillows (Nitriver ${ }^{\circledR} 3$ nitrite Reagent Set, Nitriver ${ }^{\circledR} 5$ nitrate Reagent Reagent Powder Pillow, Sulfa ver ${ }^{\circledR} 4$ Reagent Powder Pillow, SPANDS Reagent solution, Distilled Water, Ammonia Cyanurate Reagent Powder Pillows, ammonia Salicylate Reagent Pillows and High Reagent Reactive Phosphorus).

\section{Sample pretreatment strategies}

\section{Cleaning procedures of sampling materials}

Water samples have tested for some physicochemical water quality parameters and some metals constituents were collected in contaminant free plastic bottles. Glass containers have the disadvantage of breaking during the transport and interaction with inorganic constituents of the sample. All sampling materials (plastic bags, polyethylene bottles, plastic bottles and plastic scoops) were thoroughly washed with phosphate free detergent and then with distilled water before soaking in $10 \%$ nitric acid. Finally, all containers have rinsed with de-ionized water before used for sampling. In the field, the sampling bottles and caps have rinsed three times with water has been sampled prior to sampling. Cleaning has done according to the procedure described in. ${ }^{36}$

\section{Sample collection, preservation and transportation procedures}

Two liters' water sample from each sites have taken using a two-liter plastic bottle with the help of the laboratory technician. To collect the water sample, composite sampling technique has applied according to sampling procedure described in. ${ }^{37}$ That was by combining portion of multiple grab samples of equal water volumes collected at a regular time interval in a single bottle. Then, each container of the sample has labeled A, B and C with water sample description detailing the sample condition. Finally, the samples were stored in icebox and transported immediately to Woliso Polytechnic College of Water Laboratory within an hour. The contents of the container have divided in to two equal parts. Half part for physicochemical analysis and the rest were stored in an icebox at a temperature of $4^{\circ} \mathrm{C}$, and transported to Addis Ababa University Chemistry Department Laboratory and treated for heavy metals analysis. All the samples have analyzed for heavy metals such as $\mathrm{Fe}, \mathrm{Cu}, \mathrm{Zn}, \mathrm{Pb}$ and $\mathrm{Mn}$ using FAAS; and metals such as $\mathrm{Na}$ and $\mathrm{K}$ by AAS within one day from the time of sample collection.

\section{Sample digestion/preparation procedure}

In this study, by following aqueous sample digestion procedures, ${ }^{36}$ about $100 \mathrm{~mL}$ of a well-mixed and acid preserved water sample from each sample were taken in separate $250 \mathrm{~mL}$ Griffin flasks and mixed with a mixture of $2.0 \mathrm{~mL}$ of $\mathrm{HNO}_{3}(69-72 \%), 1.0 \mathrm{~mL}$ of $\mathrm{HCl}(37 \%)$ and $0.5 \mathrm{~mL} \mathrm{H}_{2} \mathrm{O}_{2}$ of $(30 \%)$ solution. The samples have gently heated on hot plate under a fume hood (Figure 3) to not more than $85^{\circ}{ }_{\mathrm{C}}$. After the digestion has completed, and then evaporated on to the lowest possible volume (about $20 \mathrm{~mL}$ ). This step takes about 2 to 3 hours for $100 \mathrm{~mL}$ aliquot with the rate of evaporation rapidly increasing as the sample volume approaches $20 \mathrm{~mL}$. Vigorous boiling has avoided preventing loss of the $\mathrm{HCl}-\mathrm{H}_{2} \mathrm{O}_{2}$ azeotrope. The flasks have covered with a watch glass to prevent sample contamination from the fume hood environment. The flasks have allowed cooling. Then, the digested samples have filtered through glass fiber filters prior to analysis. The filtrates have transferred to $50 \mathrm{~mL}$ volumetric flasks and diluted to the mark with distilled water. The digested samples have preserved in refrigerator for analysis. These solutions have then used for the elemental analysis. $\mathrm{La}\left(\mathrm{NO}_{3}\right)_{2}$ was used during spiking the sample to minimized the matrix effect.

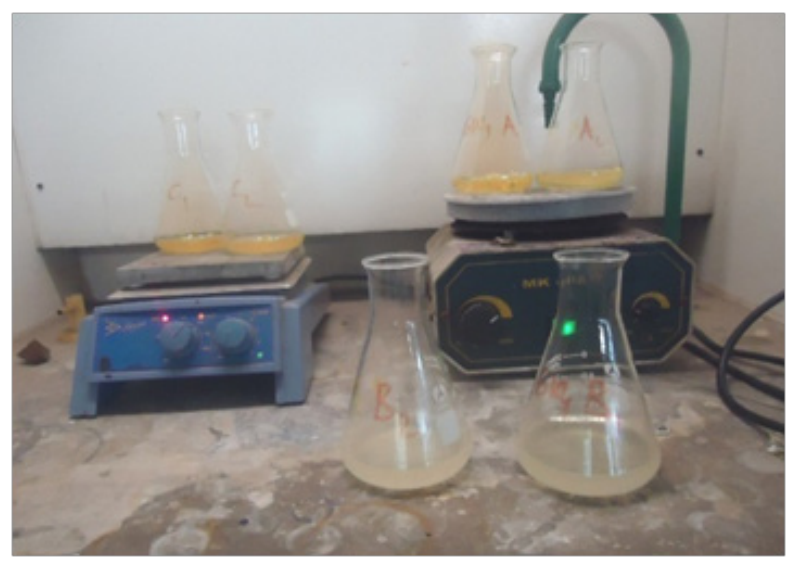

Figure 3 Sample digestions under a fume hood.

\section{Sample analysis procedure}

\section{In-Situ Measurement}

The measurement of physicochemical parameters such as temperature, electrical conductivity, total dissolved solid, turbidity, $\mathrm{pH}$, salinity and color were carried out at the site as these values might change when transported to the laboratory. Water temperature was measured in-situ, using temperature analyzer probe by dipping in water for about 2 to 3 minutes and has recorded in degree Celsius. Electrical conductivity, total dissolved solid and salinity were determined with field conductivity meter. $\mathrm{pH}$ was measured using portable digital $\mathrm{pH}$ meter. Turbidity has measured by portable turbidi meter and color was measured using comparator.

\section{Laboratory analysis procedures}

Heavy metals analysis procedures: The concentrations of heavy metals ( $\mathrm{Fe}, \mathrm{Cu}, \mathrm{Pb}, \mathrm{Zn}$ and $\mathrm{Mn}$ ) in the water samples were determined using FAAS. Standards used in establishing the analytical curve for heavy metals determinations were prepared from standard $1000 \mathrm{mg} / \mathrm{L}$ stock solution (BDH chemical Ltd-UK). The intermediate solution $(10 \mathrm{mg} / \mathrm{L})$ of each metal has then freshly prepared by diluting the stock solution in $100 \mathrm{~mL}$ volumetric flask with de-ionized water and working standard using de-ionized water. Working standards of metal solutions were prepared in $250 \mathrm{~mL}$ volumetric flask by diluting with de-ionized water and the data have given in Appendix 8. Five points of calibration curve for each metal (Appendix 8) have established by running the prepared standard solutions in atomic absorption spectrometer following the standard as described in. ${ }^{36}$ Immediately after calibration of the instrument, the sample solutions have aspired in to the AAS instrument and direct reading of the metals concentration have recorded. Calibration curves (Appendix 8) showings the absorbance versus concentration has constructed through direct analysis of five-point calibration standards at specified wavelength of the analytes. The calibration curve shows good correlation coefficient $\left(\mathrm{R}^{2}\right)$ greater than the minimum acceptance value $0.995 .{ }^{38}$ This shows that there was a good linear relationship between the concentration and instrument responses. 
Anions analysis procedures: Each anion (nitrite, nitrate, sulfate, phosphate, ammonia and fluoride) were determined separately using HACH'S Spectrophotometer set at their respective wavelength using Reagent Powder Pillows. Each individual procedures of anions determination have given in the following section as described in procedure manual. ${ }^{39}$

Nitrite $\left(\mathbf{N O}_{2}^{-}\right)$: Two sample cells were prepared. The first sample cells, was filled with $10 \mathrm{~mL}$ sample water. The content of one NitraVer 3 Nitrite Reagent Powder Pillow has added to the cell and swirled to dissolve. In 20minutes of reaction time, a pink color was developed. The second sample cell has filled with about $10 \mathrm{~mL}$ de-ionized water, which serves as a blank. This has used to calibrate the instrument to $0.0 \mathrm{mg} / \mathrm{L} \mathrm{NO}_{3}^{-}$. Then, the prepared sample in the first sample cell has inserted into the spectrophotometer and a direct reading of the concentration of $\mathrm{NO}_{2}^{-}$has recorded.

Nitrate $\left(\mathrm{NO}_{3}^{-}\right)$: A content of one NitraVer 5 Nitrate reagent powder pillow has added to $10 \mathrm{~mL}$ sample water in the first sample cell and shaken vigorously for one minute, and allowed to stand for 5minutes for an amber color development. In the second sample cell, about $10 \mathrm{~mL}$ of de-ionized water have filled. This has used as a blank to calibrate the instrument to $0.0 \mathrm{mg} / \mathrm{L} \mathrm{NO}_{3}^{-}$. Then, the sample prepared in the first sample cell has inserted into the spectrophotometer; a direct reading of the concentration of $\mathrm{NO}_{3}{ }^{-}$has recorded.

Sulphate $\left(\mathbf{S O}_{4}^{2-}\right)$ : In the first sample cell, one SulfaVer 4 Reagent Powder Pillow has mixed with $10 \mathrm{~mL}$ water sample. The mixture has allowed to react for 5 minutes and swirled vigorously to dissolve the powder. A white turbidity has formed. The blank, in the second sample cell has inserted into the cell holder to make the reading on the instrument zero. Then, the prepared sample in the first sample cell has allowed analyzing.

Fluoride $\left(\mathbf{F}^{-}\right)$: In the first sample cell, $10 \mathrm{~mL}$ of de-ionized water has mixed with $2.0 \mathrm{~mL}$ of SPADNS reagent.

In the second sample cell, $10 \mathrm{~mL}$ of the water sample and $2.0 \mathrm{~mL}$ SPADNS reagent have mixed.

Under the same condition, both the sample and the blank have allowed to react with the reagent for one minute. The prepared blank has allowed to zeroing the reading on the instrument. Then, the sample has analyzed and reading on the instrument has recorded.

Ammonia ( $\mathbf{N H}_{3}$ ): Two sample cells were prepared. To the first sample cell, $10 \mathrm{~mL}$ of the sample has mixed with one Ammonia Salicylate Powder Pillow and to the second sample cell; one Ammonia Salicylate Powder Pillow has added to $10 \mathrm{~mL}$ of de-ionized water and the two samples cells were stand for 3 minute to react. The content of one Ammonia Cyanurate Reagent has added to each solution and allowed to stand for 15 minutes. A green color was developed. Using the prepared blank in the second sample cell, the spectrophotometer has calibrated to $0.0 \mathrm{mg} / \mathrm{L} \mathrm{NH}_{3}$ and finally the prepared sample has used to determine the concentration of ammonia.

Phosphate $\left(\mathrm{PO}_{4}{ }^{3-}\right)$ : two test tube vials were prepared and using a TenSette ${ }^{\circledR}$ pipet, $5 \mathrm{~mL}$ of de-ionized water has mixed with reactive High Range Phosphorus in the first test tube vial. Into the second test tube, one Reactive High Range Phosphorus has added to $5.0 \mathrm{~mL}$ of the water sample. The two test tube vials have allowed react for seven minutes. The blank in the first test tube has used to calibrate the spectrophotometer reading to $0.0 \mathrm{mg} / \mathrm{L}$. Finally, the sample prepared has analyzed to determine the concentration of phosphate.

\section{Method validation}

\section{Evaluation of analytical precision, accuracy, recovery and quality control}

\section{Precision}

The precision of an analytical procedure has usually expressed as the variance, relative standard deviation and percentage relative standard deviation of a series of measurements. In this study, the precision of the results was evaluated by percentage relative standard deviation of the results of three samples $(\mathrm{N}=3)$ and triplicate readings for each sample giving nine measurements for a given bulk sample.

$$
\mathrm{RSD}=\frac{S D}{\bar{x}} \times 100=\mathrm{CV} \times 100
$$

Where, $\mathrm{RSD}=$ represent relative standard deviation, $\mathrm{SD}$ is standard deviation, $\bar{x}$ is the mean value and $\mathrm{CV}=$ coefficient of variance

Accuracy: Accuracy of analytical method has evaluated in terms of percent recovery by either the assay of known added amount of analyte in the sample or as the difference between the mean and the accepted true value together with the confidence intervals. In this study, the analytical accuracy of the procedures was determined by spiking experiment. The spiked sample can be prepared by adding $1 \mathrm{mg} / \mathrm{L}$ solution containing $10 \mathrm{mg} / \mathrm{L}$ each heavy metal has added to the sample. The resulted spiked samples have digested, diluted and analyzed for total heavy metals. The percentage recovery of each data has calculated as

$$
\% \text { Recovery }=\frac{[\text { means spikedvalue }- \text { unspiked value }]}{\text { standard added }} \times 100 \text {------ }(3.2
$$

Quality control: To assure and control the quality of data from sample analysis series of events like cleaning of laboratory glassware, calibration of field equipment, utilizing certified calibration standards; were performed just prior to and just after field measurements to ensure validity and accuracy of acquired data. Preparation of working standard solutions from stock solutions, calibration standard solutions, spiking metal standard mixture solution, calibration blanks/ instrument blanks, sample digestion, estimation of detection limits, and statistical data treatment have carefully carried out.

Method detection limit: Method detection limit is defined as the minimum concentration of analyte that can be identified, measured and reported with $99 \%$ confidence that the analyte concentration is greater than zero. ${ }^{40}$ Method detection limit for heavy metal may vary with wavelength selected and the spectrometer configuration and operation conditions.

Method detection limit for water sample analysis was determined using reagent water blank with $\mathrm{HNO}_{3} / \mathrm{HCl} / \mathrm{H}_{2} \mathrm{O}_{2}$ that was digested in the same condition in the condition as the sample. In this study, after digestion of three blank solutions, seven readings have taken for each blank and the standard deviations of these have calculated. The method detection limit of each element has obtained by multiplying the standard deviation of the reagent blank by three.

$$
M D L=3 x \delta_{\text {blank }} \text {-----------------------------------3.3 }
$$

$\delta_{\text {blank }}$ is standard deviation of the blank readings 


\section{Data analysis}

Data were analyzed using SPSS software (version 23) and Microsoft Excel 2007. Descriptive data have generated for all variables and have presented as means \pm standard deviation $\left({ }^{\bar{x}} \pm \mathrm{SD}\right)$. The results of the physico-chemical parameters analyzed and heavy metals concentration determined of all the three sampling site were compared with EDWQ, 2010 and WHO, 2008 standards for surface water and interpreted as acceptable or unacceptable. The mean variations in data between the three sites have analyzed using Oneway ANOVA. The parameters have correlated against each other to determine their relationship using Pearson's correlation. Significance has considered at $95 \%$ confidence interval. Differences in mean values obtained were considered significant if calculated $\mathrm{p}$-values were $<0.05$. Post Hoc Tests/ Tukey Test has also used to make pair wise comparisons between means, using any possible combinations of means for physic-chemical water quality indicator analyzed. The mean difference is significant at the 0.05 level (Table 1-5).

Table I The major sources and significance of pollution in aquatic ecosystems (Stanley, 2000)

\begin{tabular}{ll}
\hline Class of pollutant & Effects and significance \\
\hline Trace Elements & Health, aquatic biota, toxicity \\
Heavy metals & Health, aquatic biota, toxicity \\
Inorganic pollutants & Toxicity, aquatic biota \\
Algal nutrients & Eutrophication \\
Acidity, alkalinity, salinity (in excess) & Water quality, aquatic life \\
Trace organic pollutants & Toxicity \\
Polychlorinated biphenyls & Possible biological effects \\
Pesticides & Toxicity, aquatic biota, wildlife \\
Sewage, human and animal wastes & Water quality, oxygen levels \\
Biochemical oxygen demand & Water quality, oxygen levels \\
Pathogens & Health effects \\
Detergents & Eutrophication, wildlife, esthetics \\
Chemical & Carcinogens Incidence of cancer \\
\hline
\end{tabular}

Table 2 Importance of trace element in natural water (Stanley, 2000)

\begin{tabular}{|c|c|c|}
\hline Elements & Sources & Effects and significance \\
\hline Arsenic & $\begin{array}{l}\text { Mining byproduct, chemical } \\
\text { waste }\end{array}$ & Toxic, possibly carcinogenic \\
\hline Beryllium & Coal, industrial waste & Toxic \\
\hline Chromium & Metal plating & $\begin{array}{l}\text { Essential as } \mathrm{Cr}(\mathrm{III}) \text {, toxic as } \\
\mathrm{Cr}(\mathrm{VI})\end{array}$ \\
\hline Copper & $\begin{array}{l}\text { Metal plating, mining, } \\
\text { industrial waste }\end{array}$ & $\begin{array}{l}\text { Essential trace element, toxic } \\
\text { to plants and algae at higher } \\
\text { level }\end{array}$ \\
\hline Fluorine & $\begin{array}{l}\text { Natural geological sources, } \\
\text { wastes, water additive }\end{array}$ & $\begin{array}{l}\text { Prevent tooth decay at around } \\
\text { Img/L, toxic at higher level }\end{array}$ \\
\hline Iron & $\begin{array}{l}\text { Industrial waste, corrosion, } \\
\text { acid mine water, microbial } \\
\text { action }\end{array}$ & $\begin{array}{l}\text { Essential nutrient, damage } \\
\text { fixtures by staining }\end{array}$ \\
\hline Lead & $\begin{array}{l}\text { Industrial waste, mining, } \\
\text { fuels }\end{array}$ & Toxic, harmful to wildlife \\
\hline
\end{tabular}

Table continued.....

\begin{tabular}{lll}
\hline Elements & Sources & Effects and significance \\
\hline Manganese & $\begin{array}{l}\text { Industrial wastes, acid mine } \\
\text { water, microbial action }\end{array}$ & $\begin{array}{l}\text { Toxic to plants, damage fixture } \\
\text { by staining }\end{array}$ \\
Mercury & Industrial waste, mining, coal & $\begin{array}{l}\text { Toxic, mobilized as methyl } \\
\text { mercury compound by } \\
\text { anaerobic bacteria }\end{array}$ \\
Zinc & $\begin{array}{l}\text { Industrial waste, metal } \\
\text { plating, plumbing }\end{array}$ & $\begin{array}{l}\text { Essential element, toxic to } \\
\text { plants at higher levels }\end{array}$ \\
\hline
\end{tabular}

Table 3 Summaries of some major source and health effect of heavy metals under the study (Kaur, 2012, US-EPA, 1999, Weiner, 2008, Jordao et al., 2002).

\begin{tabular}{|c|c|c|c|c|}
\hline \multirow{2}{*}{$\begin{array}{l}\text { Pollu- } \\
\text { tants }\end{array}$} & \multirow{2}{*}{ Major sources } & \multirow{2}{*}{$\begin{array}{l}\text { Effect on human } \\
\text { health }\end{array}$} & \multicolumn{2}{|c|}{$\begin{array}{l}\text { Fresh water } \\
\text { quality guideline }\end{array}$} \\
\hline & & & $\begin{array}{l}\text { EDWQ, } \\
2010\end{array}$ & $\begin{array}{l}\text { WHO, } \\
2008\end{array}$ \\
\hline $\mathrm{Pb}$ & $\begin{array}{l}\text { Paint, pesticide, } \\
\text { lead storage } \\
\text { batteries, crystal } \\
\text { glass, preparation } \\
\text { fertilizers }\end{array}$ & $\begin{array}{l}\text { Cognitive } \\
\text { impairment in } \\
\text { children, cause } \\
\text { blood and brain } \\
\text { disorder, peripheral } \\
\text { neuropathy } \\
\text { in adults, } \\
\text { developmental } \\
\text { delay, decrease } \\
\text { in hemoglobin } \\
\text { production, }\end{array}$ & 0.01 & 0.01 \\
\hline $\mathrm{Cu}$ & $\begin{array}{l}\text { Copper } \\
\text { electroplating, } \\
\text { pesticide } \\
\text { production, } \\
\text { mining, common } \\
\text { copper-bearing } \\
\text { ores are } \mathrm{S}^{2-}, \mathrm{As} \text {, } \\
\mathrm{Cl}^{-} \text {, and } \mathrm{CO}_{3}^{2-}\end{array}$ & $\begin{array}{l}\text { Headache, nausea, } \\
\text { vomiting, diarrhea, } \\
\text { liver anemia, } \\
\text { cirrhosis in patients, } \\
\text { liver and kidney } \\
\text { damage. }\end{array}$ & 2.0 & 0.10 \\
\hline $\mathrm{Zn}$ & $\begin{array}{l}\text { Effluents from } \\
\text { electroplating } \\
\text { industries, } \\
\text { sewage } \\
\text { discharge, } \\
\text { fertilizers, } \\
\text { manufacture }\end{array}$ & $\begin{array}{l}\text { Vomiting, diarrhea, } \\
\text { liver and kidney } \\
\text { damage, system } \\
\text { dysfunctions }\end{array}$ & 5.0 & 0.2 \\
\hline$M n$ & $\begin{array}{l}\text { Domestic } \\
\text { waste, industrial } \\
\text { effluent, } \\
\text { atmospheric } \\
\text { dust and } \\
\text { decomposition } \\
\text { of plant material. }\end{array}$ & $\begin{array}{l}\text { Mn deficiency in } \\
\text { females causes a } \\
\text { reduced maternal } \\
\text { carrying for her } \\
\text { young The }+7 \\
\text { oxidation number } \\
\text { Mn oxidize } \\
\text { manganese and/ } \\
\text { or other organic } \\
\text { matter }\end{array}$ & 0.5 & 0.5 \\
\hline $\mathrm{Fe}$ & $\begin{array}{l}\text { Erosion of } \\
\text { minerals from } \\
\text { rocks and soil, } \\
\text { corrosion } \\
\text { of pipeline, } \\
\text { sewage from } \\
\text { metallurgical, } \\
\text { dying }\end{array}$ & $\begin{array}{l}\text { Increase the free } \\
\text { radical production, } \\
\text { which is responsible } \\
\text { for degenerative } \\
\text { diseases and ageing }\end{array}$ & 0.3 & 0.3 \\
\hline
\end{tabular}

NB. Na standard is $200.0 \mathrm{mg} / \mathrm{L}$ and $\mathrm{K}$ standard value is $1.5 \mathrm{mg} / \mathrm{L}$ in both the standards, EDWQ, (2010) and WHO, (2008) guideline 
Table 4 Water quality parameters used for testing quality of water and their sources of and potential health effect (US EPA, I999) guidelines

\begin{tabular}{|c|c|c|c|c|}
\hline \multirow{3}{*}{ Parameters } & \multirow{3}{*}{$\begin{array}{l}\text { Sources } \\
\text { Due to different dissolved } \\
\text { gases and solid }\end{array}$} & \multirow{3}{*}{$\begin{array}{l}\text { Potential health effects } \\
\text { Bitter test, corrosion, affect mucus membrane }\end{array}$} & \multicolumn{2}{|c|}{$\begin{array}{l}\text { Fresh water guideline, } \\
\text { mg/L }\end{array}$} \\
\hline & & & EDWQ, 2010 & WHO, 2008 \\
\hline & & & $6.5-8.5$ & $6.5-8.5$ \\
\hline Temp. & $\begin{array}{l}\text { Due to chemical reaction, } \\
\text { hot waste water }\end{array}$ & $\begin{array}{l}\text { Influence chemical, biochemical, biological of aquatic } \\
\text { system, effect on solubility of essential gases }\end{array}$ & - & - \\
\hline EC & $\begin{array}{l}\text { Due to different dissolved } \\
\text { solid }\end{array}$ & High conductivity increases corrosive nature of water & - & $500 \mu \mathrm{S} / \mathrm{cm}$ \\
\hline Turbidity & Soil runoff & Higher level causing bacteria & $7 \mathrm{NTU}$ & $5 \mathrm{NTU}$ \\
\hline TDS & $\begin{array}{l}\text { From the Presence all } \\
\text { dissolved salt }\end{array}$ & $\begin{array}{l}\text { Undesirable taste, gastro-intestinal irritation, corrosion, or } \\
\text { incrustation }\end{array}$ & 1000 & 1000 \\
\hline Color & Dissolved salts & Consumer acceptance decreases & I5 HU & $15 \mathrm{HU}$ \\
\hline Nitrite & $\mathrm{NH}_{3}$ compounds & Form nitrosamine's - carcinogenic & 3.0 & 3.0 \\
\hline Nitrate & $\begin{array}{l}\text { Runoff, fertilizers } \\
\text { septic tank, }\end{array}$ & $\begin{array}{l}\text { Effect on infant symptoms include shortness of breath, } \\
\text { blue-baby syndrome }\end{array}$ & $50 \mathrm{mg} / \mathrm{L}$ & $50 \mathrm{mg} / \mathrm{L}$ \\
\hline Sulphate & $\begin{array}{l}\text { Due to dissolved } \mathrm{Ca} / \mathrm{Mg} / \mathrm{Fe} \\
\text { sulphate }\end{array}$ & $\begin{array}{l}\text { Taste affect; gastro-intestinal irritation; calcium sulphate } \\
\text { scale, laxative effect }\end{array}$ & $250 \mathrm{mg} / \mathrm{L}$ & $500 \mathrm{mg} / \mathrm{L}$ \\
\hline phosphate & $\begin{array}{l}\text { Waste water from detergent } \\
\text { effluent, rocks }\end{array}$ & $\begin{array}{l}\text { Stimulate microbial growth; rancidity mould growth; algal } \\
\text { growth, eutrophication }\end{array}$ & - & $5.0 \mathrm{mg} / \mathrm{L}$ \\
\hline Fluoride & Presence of mineral salts & Dental and skeletal flourish; non-skeletal manifestation & $1.5 \mathrm{mg} / \mathrm{L}$ & $1.5 \mathrm{mg} / \mathrm{L}$ \\
\hline Ammonia & $\begin{array}{l}\text { Due to dissolved gas, } \\
\text { organics cpds }\end{array}$ & $\begin{array}{l}\text { Corrosion of } \mathrm{Zn} \text { and } \mathrm{Cu} \text { alloys by formation of complex } \\
\text { ions }\end{array}$ & $1.5 \mathrm{mg} / \mathrm{L}$ & $1.5 \mathrm{mg} / \mathrm{L}$ \\
\hline
\end{tabular}

Table 5 Instrument operation condition for AAS

\begin{tabular}{|c|c|c|c|c|c|c|}
\hline Elements & $\begin{array}{l}\text { Wave length } \\
\text { in }(\mathrm{nm})\end{array}$ & $\begin{array}{l}\text { Instrumental detection } \\
\text { limit in (mg/L) }\end{array}$ & $\begin{array}{l}\text { Slit width in } \\
(\mathrm{nm})\end{array}$ & $\begin{array}{l}\text { Current in } \\
(\mathrm{mA})\end{array}$ & $\begin{array}{l}\text { Energy in } \\
\text { (EV) }\end{array}$ & Flame system \\
\hline $\mathrm{Fe}$ & 248.3 & 0.03 & 0.2 & 7 & 71.6 & Air/acetylen \\
\hline $\mathrm{Cu}$ & 324.8 & 0.007 & 1.2 & 2 & 75.4 & “ \\
\hline $\mathrm{Pb}$ & 283.3 & 0.03 & 1.2 & 2 & 71.8 & “ \\
\hline $\mathrm{Zn}$ & 213.9 & 0.0024 & 0.5 & 2 & 100 & “ \\
\hline$M n$ & 275.9 & 0.01 & 0.2 & 5 & 76 & “ \\
\hline $\mathrm{Na}$ & 589.0 & 0.002 & 0.5 & 7 & 100 & “ \\
\hline K & 766.5 & 0.003 & 1.0 & 8 & 100 & “ \\
\hline
\end{tabular}

\section{Results and discussions}

\section{Results of method validation}

Method detection limits: The method detection limit (MDL) of the analytical method for each analytes were determined from seven replicate of blank (de-ionized water) spiked with target analyte. The calculated values (Table 6) represent the measured minimum concentration of the analytes and the values reported with $99 \%$ confidence that the analyte concentration greater than zero.

Recovery testes: The precision and accuracy of the analytical method has calculated in terms of relative standard deviation and percent recovery using equation 3.1 and 3.2 respectively. The percent calculated values have given in Table 7 . The recovery and relative standard deviation was within the standard / required limit; 80-120\% for recovery and $<20 \%$ for $\mathrm{RSD} .{ }^{38}$ Recovery values in the above range are acceptable for environmental investigations and the digestion procedure has believed to remove metals fractions associated with carbonates, sulphides, soluble salts, organic matter and Fe-Mn oxide phase. $^{4}$

According to the standard, $80-120 \%$ recovery and $\leq 20 \%$ RSD can have used as starting for assessment of accuracy and precision (APHA, $1999)^{38}$ unless other criteria are provided by a chosen laboratory. Therefore, the percentage recovery values have found between the lowest $89.6 \%$ to and highest $97.6 \%$ and all were within the required criteria. In addition, the RSD value is all below the standard limit (Table 7). This confirms that the method has provided results within the required levels of accuracy and precision. 
Table 6 Regression equation, Correlation coefficient and Detection limit

\begin{tabular}{lllll}
\hline Analyte & Regression equation & Correlation coefficient & \multicolumn{2}{c}{ Detection limit } \\
& & & IDL $^{\mathrm{a}}$ & MDL $^{\mathrm{b}}$ \\
\hline $\mathrm{Cu}$ & $\mathrm{Y}=0.255 \mathrm{x}+0.00 \mathrm{I}$ & 0.996 & 0.01 & $0.0 \mathrm{I}^{\mathrm{c}}$ \\
$\mathrm{Fe}$ & $\mathrm{Y}=0.014 \mathrm{I}+0.003$ & 0.996 & 0.02 & $3 \times 0.02=0.06$ \\
$\mathrm{Zn}$ & $\mathrm{Y}=0.014 x+0.003$ & 0.996 & 0.005 & $3 \times 0.012=0.04$ \\
$\mathrm{~Pb}$ & $\mathrm{Y}=0.014+0.003$ & 0.996 & 0.03 & $3 \times 0.02=0.06$ \\
$\mathrm{Mn}$ & $\mathrm{Y}=0.014+0.003$ & 0.996 & 0.01 & $0.0 I^{\mathrm{c}}$ \\
$\mathrm{Na}$ & $\mathrm{Y}=0.221 \times+0.042$ & 0.989 & 0.002 & $3 \times 0.03=0.09$ \\
$\mathrm{~K}$ & $\mathrm{Y}=0.221 \times+0.017$ & 0.998 & 0.005 & $3 \times 0.021=0.063$ \\
\hline
\end{tabular}

aResults are obtained from the manual of the instrument (Maiti S.K., 2004)

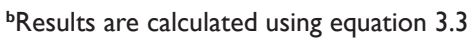

'The values for water blank were below the detection limits, hence the instrument detection limits were taken as detection limits for the metals.

Table 7 Percentage Recoveries, Standard Deviation (SD) and Relative Standard Deviation (RSD of heavy metals

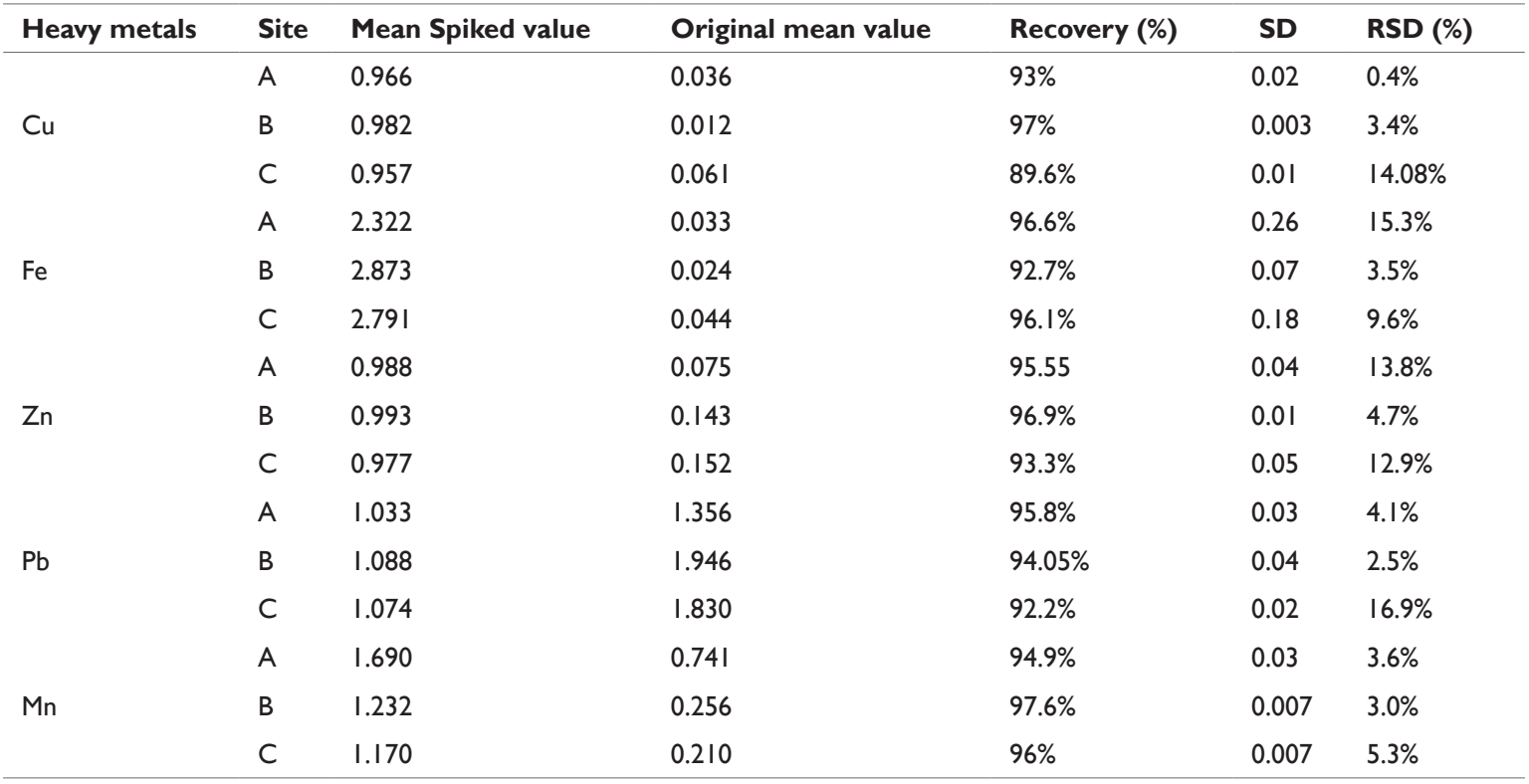

\section{Physico-chemical characteristics of water sample}

Physico-chemical variables measured for the assessment of Rebu River include: $\mathrm{pH}$, temperature $\left({ }^{\circ} \mathrm{C}\right)$, electrical conductivity $(\mu \mathrm{S} / \mathrm{cm})$, turbidity (NTU), total dissolved solid $(\mathrm{mg} / \mathrm{L})$, salinity $(\mathrm{mg} / \mathrm{L})$, color (HU), fluoride ( $\mathrm{mg} / \mathrm{L})$, nitrite $(\mathrm{mg} / \mathrm{L})$, Nitrate $(\mathrm{mg} / \mathrm{L})$, sulphate $(\mathrm{mg} / \mathrm{L})$, phosphate $(\mathrm{mg} / \mathrm{L})$ and ammonia $(\mathrm{mg} / \mathrm{L})$

pH: $\mathrm{pH}$ is a simple parameter but extremely important, since most of the chemical reaction in aquatic environment are controlled by any change in its value. In this study, the $\mathrm{pH}$ of the water sample at the three sites range from 8.2 (site A) to 10.5 (site B). As it is indicated in Table 10, the $\mathrm{pH}$ was weakly alkaline in the entire sites. The value in site A is within the maximum limit (6.5-8.5) of EDWQ (2010) and WHO (2008) guideline ranges while the value in sites B and C are above the range of maximum limit. The higher $\mathrm{pH}$ values observed suggests that carbon dioxide, carbonate-bicarbonate equilibrium has affected more due to change in physicochemical condition. ${ }^{27}$ The presence of alkali metals such as potassium increases the $\mathrm{pH}$ because of interaction between carbonates and bicarbonates formed from the dissolved $\mathrm{CO}_{2}$ and stabilized $\mathrm{CO}_{2}$. In addition, during the daytime the $\mathrm{pH}$ of a river increases due to photosynthetic activity because the consumption of $\mathrm{CO}_{2}$.

In this study, the $\mathrm{pH}$ of the river differed significantly $(\mathrm{P}<0.05)$ between the selected sites of the river and strongly correlated with dissolved solid, color, salinity, $\mathrm{NO}_{3}^{-}, \mathrm{SO}_{4}^{2-a n d ~} \mathrm{pH}(\mathrm{r}>0.9)$ but weakly correlated with $\mathrm{PO}_{4}^{3-}($ Table 8/Appendix 2$)$. Site $\mathrm{B}$ was not significantly different from site $\mathrm{C}(\mathrm{P}>0.05)$, but significantly different from site $\mathrm{A}$. Site $\mathrm{A}$ is significantly differing from site $\mathrm{C}(\mathrm{P}<0.05)$ (Appendix 3 ). The major contributor for the increase in the $\mathrm{pH}$ value of the Rebu River at site B was probably the effluent discharged from the soap and detergent factory, ammonium fertilizers used for agricultural activities. Water with $\mathrm{pH}$ value of about 10 is exceptional and may reflect contamination by strong bases such as $\mathrm{NaOH}$ and $\mathrm{Ca}(\mathrm{OH})_{2}$. High $\mathrm{pH}$ tends to facilitate the solubility of salts of ammonium and heavy metals. Alkaline $\mathrm{pH}$ can contribute to accumulation of algal bloom. High $\mathrm{pH}$ could alter the toxicity of other pollutants. 
Table 8 Correlation between physic-chemical parameters among the selected sites of Rebu River River

\begin{tabular}{|c|c|c|c|c|c|c|c|c|c|c|c|c|}
\hline \multicolumn{13}{|c|}{ Correlations } \\
\hline & $\mathrm{pH}$ & Temp & EC & Turb & TDS & Color & Salin & $\mathrm{NO}_{2}^{-}$ & $\mathrm{NO}_{3}{ }_{3}^{-}$ & $\mathrm{SO}_{4}^{2-}$ & $\mathrm{PO}_{4}^{3-}$ & $\mathrm{NH}_{3}$ \\
\hline $\mathrm{pH}$ & I & & & & & & & & & & & \\
\hline Temp & $.845^{* *}$ & I & & & & & & & & & & \\
\hline EC & $.870^{* k}$ & $.679^{*}$ & I & & & & & & & & & \\
\hline Turb & $.867^{k k}$ & $.794^{*}$ & $.767^{*}$ & I & & & & & & & & \\
\hline TDS & $.904 * *$ & $.734 *$ & $.989 * *$ & $.854^{* *}$ & I & & & & & & & \\
\hline Color & $.939 * *$ & $.736^{*}$ & $.948 * *$ & $.816^{* *}$ & $.956 * *$ & I & & & & & & \\
\hline Salin & $.903 * *$ & $.734^{*}$ & $.989 * *$ & $.855^{* *}$ & $1.000 * *$ & $.956 * *$ & I & & & & & \\
\hline $\mathrm{NO}_{2}^{-}$ & $.796^{*}$ & .618 & $.818^{* *}$ & $.872^{* *}$ & $.866^{* *}$ & $.883^{* *}$ & $.865^{* *}$ & 1 & & & & \\
\hline $\mathrm{NO}_{3}^{-}$ & $.924 * *$ & $.803^{* *}$ & $.896^{* *}$ & $.972^{* *}$ & $.952 * *$ & $.914 * *$ & $.952 * *$ & $.90 I^{* *}$ & 1 & & & \\
\hline $\mathrm{SO}_{4}^{2-}$ & $.906 * *$ & $.820^{* * *}$ & $.777^{*}$ & $.995 * *$ & $.861^{* *}$ & $.842^{* *}$ & $.861^{* *}$ & $.866^{* *}$ & $.974 * *$ & I & & \\
\hline $\mathrm{PO}_{4}^{3-}$ & $.699^{*}$ & .468 & $.915^{* *}$ & .451 & $.846^{* * *}$ & $.840^{* * *}$ & $.845^{* *}$ & .619 & .647 & .475 & 1 & \\
\hline $\mathrm{NH}_{3}$ & $.809^{* k}$ & .648 & $.701^{*}$ & $.955 * *$ & $.789^{*}$ & $.768^{*}$ & $.790^{*}$ & $.878^{* *}$ & $.916 * *$ & $.950 * *$ & .396 & I \\
\hline
\end{tabular}

**. Correlation is significant at the 0.01 level (2-tailed).

*. Correlation is significant at the 0.05 level (2-tailed).

indicate strong correlation while the indicate weak correlation

Temperature: Water temperature is one of the controlling factors for dynamics of aquatic environments; because it interferes in the organism metabolism, influencing the reproduction, accelerating the reactions' speed and increasing the degradation rate of organic matter. The present investigation reveals that the temperature the river varied from a minimum of $17.5^{\circ} \mathrm{c}$ at site $\mathrm{A}$ to a maximum of $22.5^{\circ} \mathrm{c}$ at site B. As depicted in Table 10 , water temperature at site A was lower than that of site B. This might be attribute to the fact that site $\mathrm{A}$ is located relatively in the headwater, which have more shade and located at higher altitude and no foreign wastes are daily discharge to it. The maximum temperature recorded at site B may be attributing to exothermic reaction taking place between the ionic species discharged from the effluents discharged from soap and detergent factory and municipal wastes. The water temperature during sampling period across the sampling sites was significantly different (ANOVA, $\mathrm{P}<0.05$ ) among the sites of the studied river (Appendix 1). Temperature of the river water was strongly correlated with $\mathrm{pH}(\mathrm{r}=0.84)$, turbidity $(\mathrm{r}=0.79)$, TDS $(\mathrm{r}=0.73)$, color $(\mathrm{r}=0.74)$, salinity $(\mathrm{r}=0.73), \mathrm{NO}_{3}^{-}(\mathrm{r}=0.80), \mathrm{SO}_{4}^{2-}(\mathrm{r}=0.82)$ with $\mathrm{EC}(\mathrm{r}=0.67)$, $\mathrm{NH}_{3}(\mathrm{r}=0.64), \mathrm{NO}_{2}^{-}(\mathrm{r}=0.62)$, and weakly with $\mathrm{PO}_{4}^{3-}(\mathrm{r}=0.46)$ (Table 8/ Appendix 2). There is a significant variation between sites $\mathrm{A}$ and $\mathrm{C}$ $(\mathrm{P}<0.05)$ but, site $\mathrm{B}$ is not significantly different from site $\mathrm{C}$ and site $\mathrm{A}$ is not significantly different from site $\mathrm{B}$ which indicating that there are extra foreign materials are added to site $\mathrm{B}$.

The fluctuation in river water temperature usually depends on season, geographic location, sampling time, and temperature of effluent entering the stream 6(Ahipathy, 2006). ${ }^{42}$ All aquatic life forms have characteristic temperature preference and tolerance limits. Any increase in the average temperature of a water body can have ecological impacts. It can elevate the metabolic oxygen demand which in conjugation with reduced oxygen solubility, affect many species. Increase in temperature also increases the rate of microbial activity.

Electrical conductivity (EC): EC of the water sample ranging from the minimum of $171.2 \mu \mathrm{S} / \mathrm{cm}$ (site A) to a maximum of $1592.6 \mu \mathrm{S} /$ $\mathrm{cm}$ (site B). The highest concentration value of electrical conductivity recorded were probably associated with the effluent discharge from dissolved substance from soap and detergent factory, municipal effluent discharged from resident community and chemicals applied to farm land. This value was started to decrease downstream of the river (Table 10) due to dilution effect. This may also be a sign that ions responsible for the conductivity were precipitate out or settling on the riverbed or being absorbed by aquatic plants. The mean concentration values of electrical conductivity of the river varied significantly $(\mathrm{P} \leq 0.05)$ among the sampling sites (Appendix 1). Since, the conductivity of the water is a function of the number of charged ion in solution; it is another measure of dissolved materials. This can be indicated from the strong correlation $(\mathrm{r}=0.989)$ values of total dissolved and salinity recorded. EC of the river was also strongly correlated with $\mathrm{pH}(\mathrm{r}=0.87)$, color $(\mathrm{r}=0.948), \mathrm{NO}_{2}^{-}(\mathrm{r}=0.818), \mathrm{NO}_{3}^{-}$ $(\mathrm{r}=0.896), \mathrm{SO}_{4}^{2-}(\mathrm{r}=0.777)$ and $\mathrm{PO}_{4}^{3-}(\mathrm{r}=915)$ (Appendix 2$)$. The electrical conductivity values at each site differ significantly from each other (site A differ from sites B and C, Site B differ from site C) (Appendix 3). This indicates that the amounts of dissolved ion responsible for the conductivity in the three sites are not the same due to their different in the potential sources of pollution.

The studies on Huluka River, Ambo where domestic and sewage waste water are directly discharged to the river shows that the electrical conductivity values of the river varies from 175.1 to $580.6 \mu \mathrm{S} / \mathrm{cmin}$ dry 
season, whereas, the values on Alaltu River under the same studies, varies from 497.0 to $788.4 \mu \mathrm{S} / \mathrm{cm} 58$ (Wondimu and Tesso, 2011). ${ }^{43}$ The values described here in these two rivers are below standard value prescribed for surface water. An extremely high concentration of conductivity has also recorded in Modjo River $(14330 \pm 1182.3 \mu \mathrm{S} /$ $\mathrm{cm})$, Ethiopia ${ }^{44}$ and Sebeta River $(9397.8 \pm 3.20 \mu \mathrm{S} / \mathrm{cm})$, Ethiopia. ${ }^{45}$ These two rivers are highly impacted by effluent discharged from tannery and alcohol factories. Fekayode ${ }^{6}$ on the other hand recorded un-usually high value in Alaro River, Nigeria (18000-22000 $\mu \mathrm{S} /$ $\mathrm{cm}$ ), which is much higher than Huluka, Alaltu, Modjo, Sebeta and the currently studied rivers. Generally, these findings were partly agreeing with the values of currently studied river whose potential source of the ions probably from effluent of soap and detergent factory and discharged from municipal and domestic wastes.

Table 9 Correlation between measured metals from upstream to downstream of Rebu River

\begin{tabular}{llllllll}
\hline & $\mathrm{Cu}$ & $\mathbf{F e}$ & $\mathbf{Z n}$ & $\mathbf{P b}$ & $\mathbf{M n}$ & $\mathbf{N a}$ & $\mathbf{K}$ \\
\hline $\mathrm{Cu}$ & $\mathrm{I}$ & & & & & & \\
$\mathrm{Fe}$ & -.500 & $\mathrm{I}$ & & & & & \\
$\mathrm{Zn}$ & $.760^{*}$ & -.395 & $\mathrm{I}$ & & & & \\
$\mathrm{Pb}$ & -.567 & .610 & $-.35 \mathrm{I}$ & $\mathrm{I}$ & & & \\
$\mathrm{Mn}$ & .139 & $-.745^{*}$ & -.069 & -.636 & $\mathrm{I}$ & & \\
$\mathrm{Na}$ & -.485 & .651 & -.364 & $.804^{* *}$ & $-.742^{*}$ & $\mathrm{I}$ & \\
$\mathrm{K}$ & -.614 & .506 & -.463 & $.674^{*}$ & -.581 & $.938^{* *}$ & $\mathrm{I}$ \\
\hline
\end{tabular}

**Correlation is significant at the 0.01 level (2-tailed

* Correlation is significant at the 0.05 level (2-tailed).

Red color represents negative correlation

Yellow color represents strong correlation

Pearson correlation coefficient matrix among the selected heavy metal is present in Table 9. Significant correlation between the heavy metals $\mathrm{Zn}$ and $\mathrm{Cu}(\mathrm{r}=$ $0.760), \mathrm{Pb}$ and $\mathrm{Fe}(\mathrm{r}=0.610), \mathrm{Mn}$ and $\mathrm{Cu}(r=0.139$, weakly), $\mathrm{Na}$ and $\mathrm{Fe}(\mathrm{r}=0.65 \mathrm{I}), \mathrm{Na}$ and $\mathrm{Pb}(\mathrm{r}=0.804$, strongly), $\mathrm{K}$ and $\mathrm{Fe}(\mathrm{r}=0.506), \mathrm{k}$ and Pb $(r=0.674)$ and $\mathrm{K}$ and $\mathrm{Na}(r=0.938$, strongly) could indicate the same or similar source input.

Table 10 Results of physico-chemical parameters of water samples collected from Rebu River and Statistical P-values (the values were expressed as $\bar{x} \pm$ SD, $\mathrm{n}=3$ )

\begin{tabular}{|c|c|c|c|c|c|}
\hline \multirow[b]{2}{*}{ Parameters } & \multirow[b]{2}{*}{ Site $A^{*}$} & \multirow[b]{2}{*}{ Site B* } & \multirow[b]{2}{*}{ Site C* } & \multicolumn{2}{|c|}{ Statistical p-value } \\
\hline & & & & P-value & $\begin{array}{l}\text { Significance } \\
(p=0.05)\end{array}$ \\
\hline $\mathrm{pH}$ & $8.2 \pm 0.3$ & $\dagger \mid 0.5 \pm 0.6$ & t9.5 $5 \pm 0.6$ & 0.004 & Significant \\
\hline Temp. $\left({ }^{\circ} \mathrm{C}\right)$ & $17.5 \pm 2.3$ & $22.5 \pm 1.8$ & $19.3 \pm 1.5$ & & Significant \\
\hline E.C $(\mu S / \mathrm{cm})$ & $171.5 \pm 3.2$ & $1592.6 \pm 15.2$ & $14|5 \pm 1| .0$ & 0.000 & Significant \\
\hline Turbidity (NTU) & $10.7 \pm 2.5$ & $800 \pm 6.0$ & $202.7 \pm 6.3$ & 0.000 & Significant \\
\hline TDS (mg/L) & $89.6 \pm 4.2$ & $2359.5 \pm 10.8$ & $1744.7 \pm 6.0$ & 0.000 & Significant \\
\hline Color (HU) & $9.7 \pm 3.1$ & $t_{23} \pm 3.0$ & $\dagger \mid 7.7 \pm 1.5$ & 0.001 & Significant \\
\hline Salinity (mg/L) & $84.4 \pm 4.8$ & $2440 \pm 4.6$ & $1800 \pm 9.0$ & 0.000 & Significant \\
\hline $\mathrm{F}^{-}, \mathrm{mg} / \mathrm{L}$ & Nil & Nil & Nil & - & - \\
\hline $\mathrm{NO}_{2}^{-}, \mathrm{mg} / \mathrm{L}$ & $+0.02 \pm 0.0$ & t0.58 \pm 0.1 & $t_{0} 0.28 \pm 0.2$ & 0.006 & Significant \\
\hline $\mathrm{NO}_{3}^{-}, \mathrm{mg} / \mathrm{L}$ & $10.7 \pm 1.7$ & $324.5 \pm 7.1$ & $153.5 \pm 4.5$ & 0.000 & Significant \\
\hline $\mathrm{SO}_{4}^{2-}, \mathrm{mg} / \mathrm{L}$ & $12.2 \pm 2.4$ & $96 \pm 6.2$ & $34.3 \pm 4.9$ & 0.000 & Significant \\
\hline $\mathrm{PO}_{4}{ }^{3-}, \mathrm{mg} / \mathrm{L}$ & $23.2 \pm 6.6$ & $163.3 \pm 2.5$ & $122.2 \pm 10.9$ & 0.000 & Significant \\
\hline $\mathrm{NH}_{3}, \mathrm{mg} / \mathrm{L}$ & $\dagger 6.4 \pm 0.6$ & $15.8 \pm 2.6$ & 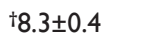 & 0.001 & Significant \\
\hline
\end{tabular}

Site $A^{*}=$ water sample from upstream of river; Site $B^{*}=$ water sample from the effluent discharge point; and Site $C^{*}=$ water sample from downstream stream the river

† Not significantly different at $5 \%$ level of probability (Appendix 3) 
The electrical conductivity values usually give an estimate of the presence of certain ions in water such as carbonate, bicarbonates, chloride, sulphate, nitrate, sodium, potassium, calcium, magnesium, all of which carry an electrical charge. ${ }^{46}$ The presence of these chemical constituents gives water the ability to conduct electricity. The EC in fresh water ranges between $10-1000 \mu \mathrm{S} / \mathrm{cm} 12$ (Chapman, 1996) ${ }^{2}$ and the Ethiopia Environmental Protection Agency 15(EEPA, $2003)^{17}$ set a standard to EC of $1000 \mu \mathrm{S} / \mathrm{cm}$ for any surface water Compared to these standards, sites B and C of Rebu River had electrical conductivity values above the minimum permissible limit. This is a clear indication of the river water contains high quantity of dissolved ionic salts that might not be safe both to humans and other domestic animals.

Total dissolved solid (TDS): is an important parameter in evaluating the suitability of water for irrigation, since the solid might clog both pores and components of water distribution system. The observed mean total dissolved solid concentration in the river water currently measured varied between a minimum mean values of $89.6 \pm 4.2 \mathrm{mg} / \mathrm{L}$ (site A) to a maximum mean values of $2359.5 \pm 10.8 \mathrm{mg} / \mathrm{L}$ (site B). The values at site $\mathrm{A}(89.6 \mathrm{mg} / \mathrm{L})$ is much below the standard set by EDWQ and WHO $(1000 \mathrm{mg} / \mathrm{L})$. However, the values at sites B and C were above the minimum permissible limit set by both EDWQ and WHO. The high values recorded in these sites probably related to pollution through discharge of effluent from soap and detergent factory, municipal and sewage wastewater discharge into the river. Similarly, ${ }^{43}$ reported that the total dissolved solid values of Hulluka River Ambo, Ethiopia in dry season were ranging from $113.8-382.5 \mathrm{mg} / \mathrm{L}$ in which the maximum values have obtained at the effluent discharge point when compared to the upstream.

Effluents with high carbon content are among high biological oxygen demand wastes, that containing animal fat which released from soap factory. This enables the total dissolved solid to be higher in discharge effluent site (Sisay, 2000). The mean total dissolved solid values varied significantly $(\mathrm{p} \leq 0.05)$ among the selected sites of the river and completely correlated $(\mathrm{r}=1.00)$ with salinity and strongly correlated with $\mathrm{pH}, \mathrm{EC}$, and color ( $\mathrm{r}>0.9$ ) (Table 8/Appendix 2). This can indicate that more colored basic salts have dissolved in the river. Result from Post Hoc Tests show that, (at $\mathrm{P}=0.05$ ) there are a great variation in mean concentration between site $\mathrm{A}$ and site $\mathrm{B}$; site $\mathrm{A}$ and site $\mathrm{C}$; and site $\mathrm{B}$ and site $\mathrm{C}$ (Appendix 3). This shows that the sources and amounts of dissolved substance in the three sites are not similar.

The dissolved salt present in the water, affect its aesthetic value as well as its physicochemical properties. High content of dissolved solid elements, affect the density of water, influences osmoregulation of freshwater in organisms, reduces solubility of gases (like oxygen) and utility of water for drinking, irrigation and industrial purposes. Total dissolved solid greater than $1200 \mathrm{mg} / \mathrm{L}$ may be objectionable to consumers and could have impacts for those who need to limit their daily salt intake example severely hypertensive, diabetic, and renal dialysis patient. ${ }^{47}$ High concentration of total dissolved solid also reduce water clarity, contribute to a decrease in photosynthesis, combine with toxic compound and heavy metals, and lead to an increase in water temperature.

Salinity: is a measure of dissolved salts in river. The mean concentration of salinity of the river under the study was ranging from a minimum of $84.4 \mathrm{mg} / \mathrm{L}$ to a maximum of $2440 \mathrm{mg} / \mathrm{L}$. Higher salinity value has recorded at effluent entry site (site B) due to the chemical effluent from the factory and municipal waste discharge that contain many organic as well as inorganic materials. A slight decrease from site $\mathrm{B}$ to site $\mathrm{C}$ has observed probably due to adsorption of many salts with the sediments at the bottom of the river course. As it was shown in Appendix 2, salinity of the river water is directly correlated to TDS ( $\mathrm{r}=1.00)$ and strongly with $\mathrm{pH}(\mathrm{r}=0.903), \mathrm{EC}(\mathrm{r}=0.989)$, and color $(\mathrm{r}=0.956)$ values of the river indicating that, at high $\mathrm{pH}$ large quantities of salts were dissolved in the river. Salinity values of the river water under the study differed significantly $(\mathrm{P}<0.05)$ (Appendix 1). Mean concentration of salt at site $A$ varies from sites $B$ and $C$; and site $\mathrm{B}$ is also varying from site $\mathrm{C}$. This is due to the salts that released to the river or naturally, present in the river is not the same in proportion throughout the entire sites of the river.

Conductivity is a good measure of total amount of salts in water and this is commonly used to determine salinity. In natural water ions usually originate from inorganic compounds present in water. High salinity may influence the growth of aquatic vegetation. Salt may decrease osmotic pressure, causing water to flow out of the plant to achieve equilibrium. Less water can be absorbed by plant, causing stunted growth and reduce yield. High salt concentrations my cause leaf tip and marginal leaf burn, leaching or defoliation.

Turbidity: Turbidity is the measure of the suspended particulate matter in a water body that interferes with the passage or dispersion of a beam of light through the water. The mean turbidity values of water sample measured at the selected sites were differed significantly $(\mathrm{P} \leq 0.05)$ across the selected sites of the river (Appendix 1). The results obtained from the river under the study shows that the maximum turbidity value of $800 \pm 6.0 \mathrm{NTU}$ (site B) and minimum turbidity value of 10.7 $\pm 2.5 \mathrm{NTU}$ (site A) were recorded. In sites B and C, the values obtained were extremely greater than the minimum permissible value of WHO $(5 \mathrm{mg} / \mathrm{L})$ and EDWQ $(7 \mathrm{mg} / \mathrm{L})$ standards for surface water. Turbidity values of the river were strongly correlated with $\mathrm{NO}_{3}$ $(\mathrm{r}=0.972), \mathrm{SO}_{4}^{2-}(\mathrm{r}=0.995)$ and $\mathrm{NH}_{3}(\mathrm{r}=0.955)$ and weakly correlated with $\mathrm{PO}_{4}^{3-}(\mathrm{r}=0.451)$ indicating the presence of nitrate, sulphate and ammonia play major role for the maximum turbidity values recorded of the river especially at the effluent discharge point. Site A is significantly different from sites B and C; and site B significantly differ from site $\mathrm{C}$ indicating that the source of pollutant causes the river to turbid is not the same through out of the courses of the river.

The result of the analysis carried on Awash River near Koka town shows the turbidity values of the river ranging from 365-502 NTU in both dry and wet season..$^{48}$ There are many factories like Shoa and Ethio tanneries, Mojo oil mill factory which discharge their raw effluent directly in to Awash River. When compared the turbidity values of the currently studied river, Rebu River, with the turbidity values of Awash River, the turbidity values of Rebu River were extremely high. These very large turbidity values recorded were probably due to not only the discharge from factory effluent (Soap and detergent factory), but also the discharge from municipal especially from domestic waste, waste water discharged from hospital, car wash garage, toilet, --- etc. which can be washed out into the Rebu River through small tributaries.

Turbidity increases the total available surface area of solids in suspension in which bacteria can grow. High turbidity reduces light penetration; therefore, it impairs photosynthesis of submerged vegetation and algae. In turn, the plant growth may suppress fish productivity. Turbidity interferes with the disinfection of drinking water and is aesthetically unpleasant. 
Color: is the measure of dissolved coloring compounds in water. The color of water sample measured ranging from $6.7 \pm 3.1 \mathrm{HU}$ (site $\mathrm{A}$ ) to $23 \pm 3.0 \mathrm{HU}$ (site B). In the studied river, it has observed that there is a gradual decrease in the value of color of the river water from the effluent discharge point to downstream of the river. The maximum color of the river at site B may due to coloring materials discharge from soap and detergent factory that uses different coloring materials in the manufacturing process and vegetation origin such as algae and weeds that found around the course of the river. Color intensity increases with increase in $\mathrm{pH}$. Results from the three selected sites were significantly different $(\mathrm{P}<0.05)$ among the sites (Appendix $1)$. When correlated with other measured parameters the values of color of the river were strongly correlated with $\mathrm{pH}(\mathrm{r}=0.939)$, EC $(\mathrm{r}=0.948)$, TDS $(\mathrm{r}=0.956)$, salinity $(\mathrm{r}=0.956)$ and $\mathrm{NO}_{3}^{-}(\mathrm{r}=0.914)$. Color of the river is not significantly differed between site $\mathrm{B}$ and site $\mathrm{C}$; but significantly different between site $\mathrm{A}$ and site $\mathrm{B}$ and between site A and site C (Appendix 3). This indicate that to site B a lot of colored materials are discharged from Soap and Detergent Factory and municipal wastes that can cause such a variation. In the study of water pollution in Megalaya, India, most of the water bodies have colored from brownish to reddish orange signifying pollution of the river and the streams mostly in the mining area.

Color in drinking water may be due to the presence of organic matter such as humic substances, metals such as iron and manganese, or highly colored industrial wastes. Drinking water should ideally be colorless (WHO, 2008). Increase in color may interfere with the passage of light thereby impeding photosynthesis. Colored water is not aesthetically acceptable to the public. The high color value of Rebu River may probably due to discharge from soap factory and dissolved vegetation found around the course of the river.

Nitrite: The mean nitrite concentration measured shows the maximum value of $0.576 \pm 0.1 \mathrm{mg} / \mathrm{L}$ (at site $\mathrm{B}$ ) and a minimum value of $0.02 \pm 0.0 \mathrm{mg} / \mathrm{L}$ (at site A). All the values measured did not exceed surface water standard set by EDWQ and WHO (3.0mg/l) at the entire sites. However, the maximum concentration has recorded at site $\mathrm{B}$, which has started to decrease downstream, is probably from agricultural chemicals and nitrogen containing chemical. The mean concentration of nitrite among the sites differed significantly $(\mathrm{P}<0.05)$. When compared to the mean concentration of nitrite $(0.51 \mathrm{mg} / \mathrm{L})$ of Sebeta River, the heavily impacted river from industrial and municipal effluent $20,{ }^{45}$ the current studied river shows same trend of contamination with nitrite ion. Nitrite is strongly correlated with nitrate $(\mathrm{r}=0.901)$ and other measured physic-chemical parameters, except temperature and phosphate (Appendix 2). This shows that the presence of nitrite could indicated by the increase in the concentration of nitrate ion. Mean concentration of nitrite at site A is not significantly varies from site $C(r>0.05)$ but, significantly varies from site $B$. Site $\mathrm{B}$ is not differ significantly from site $\mathrm{C}$ (Appendix 3) which shows that the sources of nitrite ion in the river course is not the same at the three sites. Site B has more exposed to the source of nitrite ion. Expected source of nitrite in this river can be from nitrogen containing organic matter, commercial fertilizers, and naturally from mineral rocks decomposition. Many effluents, including sewage, are rich in ammonia, which in turn can lead to increased nitrites concentration. High level of nitrite in river water may indicate pollution. It has used as a source of nutrients for plants. At high $\mathrm{pH}$ and high ammonia, the toxicity effect of nitrite is increases.
Nitrate: Nitrate represents the most oxidized form of nitrogen and the product of oxidation of nitrogenous matters and its concentration may depend on the nitrification and de-nitrification activities of microorganisms. Nitrate mean concentration range from a minimum of $10.7 \pm 1.7 \mathrm{mg} / \mathrm{L}$ ( site A) to a maximum of $324.5 \pm 7.1 \mathrm{mg} / \mathrm{L}$. The value in site A $(10.5 \pm 1.7 \mathrm{mg} / \mathrm{L})$ was below the permissible limit of WHO and EDWQ $(50 \mathrm{mg} / \mathrm{L})$ as shown in Table 10 . Because, natural waters in their unpolluted state contain only minute quantities of nitrate. The maximum result was recorded at site B $(324.5 \pm 7.1 \mathrm{mg} / \mathrm{L})$ which was above the maximum permissible limit. The major expected source of nitrates are from the use of nitrogen containing fertilizers, domestic sewage, municipals discharge, animal manure used on cropland, and naturally from atmospheric deposition and the oxidation of ammonia. Mean concentration of nitrate in the studied river varied significantly $(\mathrm{P} \leq 0.05)$ across the selected sites (Appendix 1). The correlation coefficient value shows that the nitrate concentration is strongly correlated with all the measured physic-chemical parameters $(r>0.9)$ and weakly correlated with phosphate (Table 8/Appendix 2). Site A significantly differ from both sites $\mathrm{B}$ and $\mathrm{C}$; and site $\mathrm{B}$ varies from site $\mathrm{C}$. the variation may be due to the different source of nitrate ion discharge to the three sites of the river.

When the results of the studied river compared with the impacted Sebeta River with maximum nitrate mean concentration of 4.99 \pm 2.88 , (Admasu, 2007), and 4.17 to $8.27 \mathrm{mg} / \mathrm{L},{ }^{45}$ as a result of Bale zaf alcohol and soap factory effluent at downstream, Rebu River is heavily polluted with nitrate ion. In another study, the measured mean concentration of nitrate in both Little and Great Akaki River were 189 \pm 319 and $8 \pm 11 \mathrm{mg} / \mathrm{L}$ respectively. ${ }^{9}$ In both rivers, where seasonal variations have compared, the mean values of $\mathrm{NO}_{3}{ }^{-}$ion of the Little Akaki River recorded was very high, which was explained due to natural abundance of nitrate in the soil as part of nitrogen cycle. Both, however, shows a huge variation which could be a result of different diffusion sources such as domestic, municipal and industrial wastes effluent. A similar trend was observed in the river currently studied, Rebu River.

The presence of nutrients (nitrate, ammonia and phosphate) in the river has attributed to the processes of organic mineralization of nitrates and phosphates derived principally from the surface runoff from the immediate vicinity (forest, farm and communities) perhaps by in situ mineralization. ${ }^{49}$ The high concentration of nutrients like nitrate and nitrites could deplete the amount of dissolved oxygen in water. This in turn affects the biomass and species diversity of aquatic organism.

Phosphate $\left(\mathrm{PO}_{4}{ }^{3-)}\right.$ : Phosphate determination is useful in measuring the water quality since it is an important plant nutrient and may play a role of limiting factor among all other essential plant nutrients. The concentration of $\mathrm{PO}_{4}^{3-}$ in the studied river varies from the minimum of $23.2 \pm 6.6 \mathrm{mg} / \mathrm{L}$ (site A) to the maximum of $163.3 \pm 2.5 \mathrm{mg} / \mathrm{L}$ (site B). In the entire site, the concentration of phosphate is above the maximum limit set by WHO as well as EDWQ $(5 \mathrm{mg} / \mathrm{L})$ standard. In this study, the maximum mean concentration of $\mathrm{PO}_{4}^{3-}$ was recorded at the effluent discharge point (site B) was might be due to the discharge from soap and detergent factory, domestic waste, fertilizers and biological process. When phosphate detergents are used, disposal of the wastewater is an issue. Mean concentration of phosphate differed significantly $(\mathrm{P} \leq 0.05)$ among the sites of the river (Appendix 1). From Pearson correlation, it is observed that phosphate concentration 
is strongly correlated with $\mathrm{EC}(\mathrm{r}=0.915)$ and weakly correlated with temperature $(\mathrm{r}=0.46)$, turbidity $(\mathrm{r}=0.451)$, sulphate $(\mathrm{r}=0.475)$ and ammonia $(\mathrm{r}=0.396)$. Mean concentration of phosphate at sites A, B and $\mathrm{C}$ are varying significantly from one another $(\mathrm{P}<0.05)$ (Appendix 3 ).

Wondimu and $\mathrm{Tesso}^{43}$ in their study on Huluka River Ambo, Ethiopia reported the maximum concentration of phosphate, $1.75 \mathrm{mg} / \mathrm{L}$ at downstream, where high domestic and municipal discharges have pronounced. Similarly, the values of phosphates in the studied river, Rebu River, increased toward the discharge point and started to decrease downstream. Elevated concentration of $\mathrm{PO}_{4}^{3-}$ ion in the river is characteristic of natural contact with minerals, domestic and municipal sewage water and discharge from Soap and detergent factory effluent. The decomposition of plant materials, which have potential to release phosphate, could explain the higher concentration. In the Unite State, about half of the phosphate in sewage comes from human waste product, and $20-30 \%$ comes from detergents. ${ }^{50}$

The breakdown of phosphorus complexes in detergent wastewater (and other household products, as well as human and industrial wastes that contain phosphate) creates freely available phosphates; these can contribute to an oversupply of phosphate in waterways and cause imbalance of the aquatic ecosystem. This result in excessive algal growth and increasing the number of decomposer organism that requires oxygen, which can deplete the amount of oxygen dissolved in the water. Excessively large number of decomposers may reduce the oxygen levels to the extent that other aquatic organisms die from lack of oxygen. ${ }^{51}$

Sulphate $\left(\mathbf{S O}_{4}{ }^{2-}\right)$ : Mean sulphate ion concentration in the three sites studied ranges from a minimum of $12.2 \pm 2.4 \mathrm{mg} / \mathrm{L}$ (site A) to a maximum of $96 \pm 6.2 \mathrm{mg} / \mathrm{L}$ (site B) values. In the entire sites, the values were below the limit of the standard EDWQ $(250 \mathrm{mg} / \mathrm{L})$ and WHO $(500 \mathrm{mg} / \mathrm{L})$ above which the sulphate pollution reported to cause adverse effects on aquatic ecosystem. Generally, the mean concentrations of $\mathrm{SO}_{4}^{2-}$ were very low and decreased downstream. Statistical data analysis indicates that the mean concentration of sulphates differed significantly $(\mathrm{P} \leq 0.05)$ among the sites of the river (Appendix 1). Sulphate ion concentration is strongly correlate with all measured parameters except phosphate $(\mathrm{r}=0.475)$ that is weakly correlated (Appendix 2). Because the two ions could probably, form precipitate with metal ions and cannot affect each other. Post Hoc Test, shows that mean concentration of sulphate at site A differ significantly from site B and site C. Site B also significantly differ from site C. A study on Hulluka River Ambo, Ethiopia reported that, maximum concentration of $\mathrm{SO}_{4}{ }^{2-}$ ion has recorded at site $\mathrm{S} 5,(55.9 \mathrm{mg} / \mathrm{L})$, effluent discharge site. ${ }^{43}$ Similarly, it has shown that the concentration of sulphate increases toward the impaired site (site B) of the currently studied river. The low level of sulphate recorded at the downstream of the river could attribute to the co-precipitation of sulphates with metal ions.

In the studied river, the major expected sources of sulphate can be probably from biochemical decomposition of plants and animal's protein (in aerobic condition) and industrial effluents from soap and detergent factory as well as agricultural runoff. Large amount of $\mathrm{SO}_{4}^{2-}$ may release to the river from water treatment plant of the town which uses $\mathrm{Al}_{2}\left(\mathrm{SO}_{4}\right)_{3}$ for coagulation process. Sulphates are one of the least toxic anions and large quantities would have to be ingested in order to health disorder to occur (especially diarrhea type symptoms).
They also cause water hardening and therefore high levels are not recommended.

Flouride ( $\left.\mathbf{F}^{-}\right)$ion: Naturally, fluoride has found in low concentration in water and foods. Water with underground sources is more likely to have higher levels of fluoride. Fresh water supplies generally contain between $0.01-0.3 \mathrm{mg} / \mathrm{L}$. In the study area, fluoride ion is the only parameter that has not detected in all the sampling sites of the studied river. Hence, $\mathrm{F}^{-}$is not supposed to be a problem for domestic use of water from this river.

Ammonia $\left(\mathbf{N H}_{3}\right)$ : The mean concentration of ammonia at sites $\mathrm{A}, \mathrm{B}$, and $\mathrm{C}$ were $6.4 \pm 0.6 \mathrm{mg} / \mathrm{L}, 15.8 \pm 2.6 \mathrm{mg} / \mathrm{L}$ and $7.8 \pm 0.4 \mathrm{mg} / \mathrm{L}$ respectively. It has seen that the mean concentration of ammonianitrogen in the river water is decrease almost by half, with increase in distance from effluent discharge point (site B). The maximum result has recorded at site $\mathrm{B}$, industrial effluent site. In all the entire sites, the values measured were above the maximum limit set by EDWQ and WHO $(1.5 \mathrm{mg} / \mathrm{L})$ standards for surface water. The reduction of ammonia downstream of the effluent discharge point has attributed to the fact that, at high $\mathrm{pH}$ most ammonia will be in gaseous state, therefore, the gas volatilizes as the river flow. The mean concentration of ammonia differed significantly $(\mathrm{P} \leq 0.05)$ among the sites (Appendix 1) with highest variation value recorded at site B. Mean ammonia concentration was strongly correlated with turbidity, nitrite and nitrate $(r>0.9)$ and weakly correlated with phosphate $(r<0.5)$ (Appendix 2). This positive correlation of ammonia with $\mathrm{NO}_{2}{ }^{-}$and $\mathrm{NO}_{3}{ }^{-}$indicate that the presence of ammonia influences the concentration of $\mathrm{NO}_{2}^{-}$and $\mathrm{NO}_{3}{ }^{-}$in the river water and are came from the same sources. Post Hoc Test result (Appendix 3) shows that the mean vale of ammonia at site $\mathrm{A}$ is not significantly differ from site $\mathrm{C}$ but significantly differ from site B. Site B is significantly different from site C. This shows that the source of ammonia at site B is not the same with that at site A and C.

High amount of ammonia causes an increase in $\mathrm{pH}$ and ammonia concentration in the blood of the fish, which can damage the gills, the red blood cells, affect osmoregulation, reduce oxygen carrying capacity of blood, and increase the oxygen demand of tissues. ${ }^{1}$ Ammonia is much more toxic in alkaline waters than in acidic once because free ammonia in high $\mathrm{pH}$ values is more toxic to aquatic biota than when it is in the oxidized form. ${ }^{44}$ Artificial fertilizers used by the local community can contribute to the presence of ammonia in the river under the study.

\section{Concentration level of the measured metals of the water sample}

Heavy metals concentrations in surface water and sediments is influenced by impute from source, character of sediment, organic materials, temperature and sometimes the mineral composition of underlying rock in the area where the surface water situated. Thus, spatial and temporal variation in heavy metals concentration in sediments and especially in water should be naturally expected (Amadi et al., (2014) and Tonko, (1989, cited in 23Ja' afar, 2015)). ${ }^{52}$

In the present study, significant variations have indicated by the concentration of the metals with higher concentration shown at effluent discharge site except for few. Table 11 contains the results of the laboratory analysis conducted on the water samples from River Rebu and their detail discussions have given in the following section. 
Table I I Results of mean concentration of selected metals of water sample of Rebu River from upstream to downstream and Statistical P-value (the values were expressed as $\bar{x} \pm \mathrm{SD}, \mathrm{n}=3$ )

\begin{tabular}{llllll}
\hline Selected metals & $\begin{array}{l}\text { Site } \mathbf{A}^{*} \\
(\mathbf{m g} / \mathbf{L})\end{array}$ & $\begin{array}{l}\text { Site } \mathbf{B}^{\psi} \\
(\mathbf{m g} / \mathbf{L})\end{array}$ & $\begin{array}{l}\text { Site } \mathbf{C}^{\ddagger} \\
(\mathbf{m g} / \mathbf{L})\end{array}$ & \multicolumn{2}{c}{ Statistical P-value } \\
& $0.05 \pm 0.02$ & $0.08 \pm 0.00$ & $0.07 \pm 0.01$ & 0.019 & Significant \\
\hline Copper & $1.70 \pm 0.26$ & $2.02 \pm 0.10$ & $1.87 \pm 0.20$ & 0.176 & Not significant \\
Iron & $0.29 \pm 0.04$ & $0.21 \pm 0.01$ & $0.39 \pm 0.10$ & 0.004 & Significant \\
Zinc & $0.07 \pm 0.00$ & $0.16 \pm 0.00$ & $0.12 \pm 0.02$ & 0.048 & Significant \\
Lead & $0.82 \pm 0.03$ & $0.23 \pm 0.01$ & $0.13 \pm 0.01$ & 0.004 & Significant \\
Manganese & $8.80 \pm 1.20$ & $1557.6 \pm 7.60$ & $816.6 \pm 6.50$ & 0.000 & Significant \\
Sodium & $3.50 \pm 0.20$ & $22.3 \pm 0.40$ & $10.4 \pm 0.40$ & 0.001 & significant \\
Potassium & & & & & \\
\hline
\end{tabular}

Site $A^{*}=$ water sample from upstream of Rebu river; Site $B \Psi=$ water sample from the effluent discharge point; and Site $C \ddagger=$ water sample from downstream

Copper $(\mathbf{C u})$ : The concentration of copper in the water sample under the study ranges from a minimum of $0.05 \pm 0.02 \mathrm{mg} / \mathrm{L}$ (site A) to a maximum of $0.08 \pm 0.00 \mathrm{mg} / \mathrm{L}$ (site B). None of the sites of the river water samples analyzed for $\mathrm{Cu}$ shows above the recommended limit set by EDWQ $(2 \mathrm{mg} / \mathrm{L})$ and WHO $(0.1 \mathrm{mg} / \mathrm{L})$ guidelines. Although the values recorded at the three sites showed concentration, below the standard recommended for fresh surface water, there are indications of the presence of this metal in the river. This shows that the metal concentration in the water were generally low. However, it was observed that sample collected from the sites of effluent discharge point (site B), shows higher value of $\mathrm{Cu}$. Across the sampling sites, the concentration of $\mathrm{Cu}$ was differing significantly (ANOVA, $\mathrm{P}<0.05$ ) (Appendix 4). The copper in the river is strongly correlated with $\mathrm{Zn}$ $(\mathrm{r}=0.760)$ and weakly correlated with $\mathrm{Mn}(\mathrm{r}=0.139)$. However, this metal has negatively correlated with $\mathrm{Fe}, \mathrm{Pb}, \mathrm{Na}$ and $\mathrm{K}$ ) (Appendix 5). This is a good indication that the source of the metals $\mathrm{Cu}, \mathrm{Zn}$ and $\mathrm{Mn}$ is the same and the presence of the one can affect the other. The low values observed in the river provide an indication that there is a low usage of $\mathrm{Cu}$ containing materials and potential contamination by these metals within the sampling sites is minimal. Considering the guideline, the river water can considered wholesome with respect to copper content. This implies the river water may be safe from this metal pollution. The source for the presence of copper in the river can be from agricultural chemicals of copper compounds, corrosion of copper containing alloys in pipefitting, may introduce measureable amounts of copper into water in a pipe system. $\mathrm{Cu}$ is more of essential trace element, but toxic to plants and algae at higher level. It also impairs an undesirable taste to water.

Iron (Fe): Mean iron concentration of the river ranges from minimum value of $1.70 \pm 0.30 \mathrm{mg} / \mathrm{L}$ ( site A) to the maximum value of $2.02 \pm 0.10 \mathrm{mg} / \mathrm{L}$ (site B). When compared with maximum permissible limit of WHO and EDWQ guideline, Fe concentration in the entire sites was above the maximum acceptable limit $(0.3 \mathrm{mg} / \mathrm{L})$. In the study on Awash River, the average total concentration of Fe measured shows that, the value at site S3 (at effluent discharge point) was tenfold $(0.668 \mathrm{mg} / \mathrm{L})$ higher than that of site, $\mathrm{S} 1$ which was $0.089 \mathrm{mg} / \mathrm{L} .48$ The values of Fe concentration in Awash River were higher than the standard. ${ }^{11}$ Similarly, the Fe concentrations of the current studied river in all sites were higher than the standard set by EDWQ and WHO $(0.3 \mathrm{mg} / \mathrm{L})$. A slight decrease in concentration of Fe downstream, from site $\mathrm{B}$ to site $\mathrm{C}$ has observed. This probably due to iron tendency to form complex ligands (compounds) with anions and iron in lower oxidation is easily soluble and could settle on the riverbed. Statistical ANOVA result $(\mathrm{P}>0.05)$ shows that the mean concentration of $\mathrm{Fe}$ among the three sampling site was not significantly different (Appendix 4). This indicates iron in the river water came almost from similar sources. Pearson correlation coefficient shows that, Fe was strongly correlated $(\mathrm{r}>0.5)$ with $\mathrm{Pb}$, and $\mathrm{Na}$, weakly with $\mathrm{K}(\mathrm{r} \cong 0.5)$ and negatively with $\mathrm{Cu}, \mathrm{Zn}$ and $\mathrm{Mn}$ (Table 9/Appendix 5).

The maximum results at site $\mathrm{B}$, indicates that the site has heavily contaminated with $\mathrm{Fe}$ that accounting to a multiple factor of which frequent disposal waste from the municipal. Small-scale micro industries (example metal production, welding, car wash, etc.) practiced in the town especially at the side of the studied river probably associated with the high value of iron concentration recorded. The earth's core has believed to consist largely of a metallic iron-nickel alloy. Studies from other parts of the world documented Fe to have considerable effects on alveolar epithelial cell. Even though allowed limit is necessary for normal human health, higher concentrations are associated with stomach and intestinal corrosion, leading to bleeding and shock development. The shortage of iron causes diseases called "anemia" and prolonged consumption of drinking water with high concentration of iron may lead to liver disease called as haermosiderosis. ${ }^{53}$

Zinc: Zinc is one of the important trace elements that play a vital role in the physiological and metabolic process of many organisms. It is an essential trace element for bacteria, plants and animals including humans. It also plays an important role in protein synthesis and is a metal, which show low concentration in surface water due to its restricted mobility from the place of rock weathering or from natural source.$^{53}$ The measured concentration of zinc in the studied river was ranging from minimum of $0.21 \pm 0.01 \mathrm{mg} / \mathrm{L}$ (Site B) to the maximum of $0.39 \pm 0.05 \mathrm{mg} / \mathrm{L}$ ( site $\mathrm{C}$ ). In the entire sites, the concentrations recorded were higher than WHO $(0.2 \mathrm{mg} / \mathrm{L})$ permissible level for surface water, but lower than the EDWQ $(5.0 \mathrm{mg} / \mathrm{L})$ guideline. A decrease in the concentration of $\mathrm{Zn}$ at site $\mathrm{B}$, which followed with increase downstream, has observed. The decrease in mean concentration of $\mathrm{Zn}$ at site B might be due to formation of some insoluble salts with certain anions that might be discharge from the nearby soap factory effluent. 
In the study on Awash River water, the average total concentration of $\mathrm{Zn}$ at site $\mathrm{S} 3$ (to downstream of effluent discharge point) was ten-fold $(0.1469 \mathrm{mg} / \mathrm{L}$ of $\mathrm{Zn})$ higher than that of siteS1 which was $0.0869 \mathrm{mg} / \mathrm{L}$ $\mathrm{Zn}{ }^{48}$ However, the values were lower than the recommended safety thresholds for drinking water (WHO, 2008). ${ }^{11}$ This implies that, the value was not significantly higher than the natural elemental level in fresh water. Similarly, in the studied river the average concentration of $\mathrm{Zn}$ has observed to increase downstream. The mean concentration of $\mathrm{Zn}$ among the three sites of the river (ANOVA, $\mathrm{P}<0.05$ ) was varied significantly (Appendix 4). Zinc is strongly correlated with copper $(r=0.760)$ but, negatively correlated with the other metals analyzed (Appendix 5). This may be a result of precipitation of the element as hydrous metal oxide. A very high concentration of zinc has known to be harmful to the body. It causes phytotoxicity and affects many function of the body such as reproduction, skin health, sense of smells and tastes, brain function and growth. The frequent intake of zinc supplements can cause copper deficiency, because zinc inhibits absorption of copper in the body.

Lead (Pb): Seriously, hazardous species found in the river of the studied sites is lead. The values of lead ranging from a minimum $0.07 \pm 0.00 \mathrm{mg} / \mathrm{L}$ (site A) to a maximum $0.16 \pm 0.00 \mathrm{mg} / \mathrm{L}$ (site B). In all the entire selected sites of the river, the values recorded were above the minimum permissible limit of EDWQ and WHO $(0.01 \mathrm{mg} / \mathrm{L})$. Statistical ANOVA results (Appendix 1) shows that, among the sampling sites the mean concentration of $\mathrm{Pb}$ was significantly different $(\mathrm{P}<0.05)$ (Appendix 4). $\mathrm{Pb}$ concentration strongly correlated with $\mathrm{Na}$ $(\mathrm{r}=0.804), \mathrm{Fe}(\mathrm{r}=0.610), \mathrm{K}(\mathrm{r}=0.674)$ and negatively with copper, zinc, and manganese (Appendix 5). More recently, cases of lead poisoning have reported in zamfara state, Nigeria. It has concluded that, lead contamination of water bodies (streams and rivers) and environment lead to the death of several people and animals. Most of the lead we take has removed from our bodies in urine; however, as exposure to lead is cumulative over time, there still risk of buildup, particularly in children. Lead concentrations have effect on three human systems: blood forming system, nerve system and renal system.

In the studied river, car wash, domestic waste, deteriorating household paints, disposal of lead batteries from garage, which have discharged through small tributaries that passing through the center of the town has probably attributed to the increase in $\mathrm{Pb}$ concentration. The agricultural activities practiced around the river may also contributed to the observed high levels of lead, since this metal can occur as impurities in fertilizers and metal based pesticides and compost and manure.

Manganese (Mn): Measured mean concentration of Mn ranges from a minimum value of $0.13 \pm 0.01 \mathrm{mg} / \mathrm{L}$ at site $\mathrm{C}$ to a maximum value of $0.82 \pm 0.03 \mathrm{mg} / \mathrm{L}$ at site A. Results from sites B and C are below the minimum value set by EDWQ and WHO $(0.5 \mathrm{mg} / \mathrm{L})$ for surface water. However, a maximum value $0.82 \pm 0.03 \mathrm{mg} / \mathrm{L}$ (at site A) recorded was probably from natural deposition of Mn containing compounds. Generally, a decrease in concentration of $\mathrm{Mn}$ has observed at downstream. Similarly, Jonathan (2010) determined the level of Mn in Kwekwe River, Zimbabwe and observed that there was slight decrease in Mn concentration downstream of the effluent discharge point from iron and steel company and it has reported that, manganese precipitates at higher $\mathrm{pH}$.

Statistical results from ANOVA $(\mathrm{P}<0.05)$ shows that the mean concentration of $\mathrm{Mn}$ was varied significantly among the three sites
(Appendix 4). Mn is weakly correlated with copper $(\mathrm{r}=0.139)$ and negatively correlated with other metals that are analyzed (Appendix 5). From the correlation coefficient it has concluded that the presence of the analyzed metals has, no effect on the concentration of $\mathrm{Mn}$ as well as their presence in river is not from the same source. Major source of this heavy metal may be from atmospheric deposition, contamination of water in natural geologic deposition, manufacturing process related to chemicals and metals, discharge of municipal waste and domestic waste (James, 1991). Nutritional deficiency of Mn in man has not evaluated as a health hazard.

Sodium (Na): $\mathrm{Na}$ concentration of the water sample range from a minimum value of $8.8 \pm 1.2 \mathrm{mg} / \mathrm{L}$ (site A) to the maximum value of $1557.6 \pm 7.6 \mathrm{mg} / \mathrm{L}$ (site B). It has observed that, at downstream of the river the concentration of sodium decrease almost by half. Results from sites B and C were above the permissible level set by EDWQ and WHO $(200 \mathrm{mg} / \mathrm{L})$. There was significant difference in the mean concentration of $\mathrm{Na}$ between the three selected sites (ANOVA, $\mathrm{P}<0.05$ ). Sodium concentration is strongly correlated with $\mathrm{K}$ $(\mathrm{r}=0.938), \mathrm{Pb}(\mathrm{r}=0.804)$; weakly with $\mathrm{Fe}$ and negatively with $\mathrm{Cu}$, $\mathrm{Zn}$ and Mn (Table 9/Appendix 5). The major source that attributed to very high concentration of $\mathrm{Na}$ measured at site $\mathrm{B}$ were effluents from the soap and detergent factory that uses caustic soda $(\mathrm{NaOH})$ as a major raw material for soap manufacturing and sodium citrate and sodium silicate to produce liquid detergents; and naturally from sodium salts. Sodium is a mineral found naturally in some drinking water. Too much sodium have identified as a risk factor for high blood pressure.

Potassium (K): Potassium is one of important macronutrient elements necessary for plant growth that is absorbed in the form of $\mathrm{K}^{+}$ion. Mean concentration of potassium range from $3.5 \pm 0.20 \mathrm{mg} / \mathrm{L}$ (site A) to $22.3 \pm 0.40 \mathrm{mg} / \mathrm{L}$ (Site B).There was a decrease in concentration of $\mathrm{K}$ from site $\mathrm{B}$ to site $\mathrm{C}$. However, the values measured in all the sites were above standards, EDWQ and WHO $(1.5 \mathrm{mg} / \mathrm{L})$. K concentration varied significantly (ANOVA, $\mathrm{P}<0.05$ ) among the sampling sites (Appendix 4). Mean concentration of $\mathrm{K}$ is strongly correlated with mean concentration of $\mathrm{Na}(\mathrm{R}=0.938)$ and $\mathrm{Pb}(\mathrm{R}=0.674)$ and negatively correlated with $\mathrm{Zn}$ and $\mathrm{Mn}$ (Table 9/Appendix 5). Major source attributed to the high value of $\mathrm{K}$ in the river may be from waste discharged from soap and detergent factory and agricultural chemicals (artificial fertilizers like $\mathrm{KNO}_{3}$ ) added to soil. Naturally, sources of $\mathrm{K}$ in natural water are hydrolytic decomposition of magma rocks due to weathering, erosion of sedimentary rock, forest fire runoff and municipal, industrial and agricultural sewage. The concentration of potassium in natural water is much smaller than of sodium ones, and salts of potassium are better soluble than that of sodium. It is because; $\mathrm{K}^{+}$ion has absorbed by soil and rocks better than $\mathrm{Na}^{+}$. Potassium facilitates the process of photosynthesis and protein synthesis. It also adjusts stomata movement. Potassium is an essential element in human nutrition, and there are no limits on the amount, that can be present in drinking water.

The mean concentration of the metals in the studied river, varied in the order of $\mathrm{Na}>\mathrm{K}>\mathrm{Fe}>\mathrm{Mn}>\mathrm{Zn}>\mathrm{Pb}>\mathrm{Cu}$. Except due to the presence of $\mathrm{Na}$ and $\mathrm{K}$, the order of the other heavy metals was the same to that Yamuna River. ${ }^{30}$ The presence of these metals in the river has attributed to anthropogenic activities dominantly domestic and municipal discharge. Natural decomposition of mineral rocks can also be a source for the presence of the metals. The high concentration 
of measured metals in water samples during dry season under the study period was also due to the fact that, water levels decrease in river, results in increase in concentration of the metals. The observed decrease in concentration of ions at downstream sites of the effluent discharge point has attributed to precipitation and co-precipitation of these ionic species.

\section{Conclusion and recommendation}

The assessment of water sample for physico-chemical parameters and heavy metals from the river showed a significant variation amongst the different sites in most of the measured parameters. The variation was due to the difference in the sources of effluent discharged to the river where site $\mathrm{B}$ was with more significant variation than the other two sites. Generally, the following conclusions have drawn from this study:

i. It can be seen that the concentration of different studied physicochemical parameters such as $\mathrm{pH}$, EC, TDS, salinity, color, turbidity, $\mathrm{NO}_{3}^{-}, \mathrm{PO}_{4}^{3-}$ and $\mathrm{NH}_{3}$ were above the permissible limit set by EDWQ, 2010 and WHO, 2008. With respect to the parameters there was quite high level of water pollution especially, at effluent discharge site, site B. This may be due to direct discharge of effluent from Soap and Detergent Factory, agricultural chemicals and municipal discharge. High values of nutrients such as $\mathrm{NO}_{3}^{-}$, $\mathrm{PO}_{4}^{3-}$ and $\mathrm{NH}_{3}$ also attributed from the natural decomposition of plant matter

ii. Based on the values recorded, pollution level of the three sites of the river may be assumed with the following sequence, site $\mathrm{B}>\mathrm{C}>\mathrm{A}$. Even though, the sample water tested were found to be rich in plant nutrients required for plant growth, but due to the presence of high level toxic heavy metals $(\mathrm{Pb}, \mathrm{Mn}$ and $\mathrm{Fe})$; and $\mathrm{Na}$, the river water may not good for irrigation as well as domestic purpose.

iii. The high concentration of $\mathrm{Na}$ and $\mathrm{K}$ recorded at site $\mathrm{B}$ has directly linked with the effluent discharge from Soap and Detergent Factory. As the factory uses $\mathrm{NaOH}$ and $\mathrm{KOH}$ as a raw material for soap manufacturing process, this lead to the conclusion that the factory discharges its raw wastes directly to the river or they are using old and un updated machine in the waste treatment plant.

iv. It has seen from this work again the decrease in the level of pollution downstream of the river were due to dilution of the effluent discharged, capability of some ions to form precipitation, volatility tendency of some parameters, and absorbability of some ions with aquatic plants and animals are some expected reasons.

v. The continued discharge of effluents into river, apart from making the river unsightly, rendered the water useless for domestic usage, instilled undesirable effects on the biotic community. This investigation revealed that there was an extreme adverse impact of effluent from soap and detergent factory and municipal discharge. Finally, government and any responsible authorities should support further study that has conducted on other physical, chemical and untested biological parameters of significant health concern and on identification of potential sources of the contaminants of this river.

\section{Acknowledgements}

None.

\section{Conflict of interest}

The author declares no conflict of interest.

\section{References}

1. Lawson E. Physico-Chemical Parameters and Heavy Metal Contents of Water from the Mangrove Swamps of Lagos Lagoon, Lagos, Nigeria. Advances in Biological Research. 2011;5(1):8-21.

2. Chapman D. Water Quality Assessments. A guide to the use of Biota Sediments and Water in Environmental Monitoring. London, New York: The use of biological materials and river E IFN SPON; 1996. 651 p.

3. Mendie U. The Nature of Water. In: The Theory and Practice of Clean Water Production for Domestic and Industrial Use. Lagos: Lacto-Medals Publishers. 2005. p. 1-21.

4. Karr I. Biological integrity: A Long-Neglected Resource Management. Ecological Applications. 1991;1(1):66-84.

5. Mokaye S, Mathooko I, Leiothfried M. Influence of anthropogenic activities of water quality of tropical stream ecosystem. Afr J Eco. 2004;42(4):281-288.

6. Fakayode S. Impact assessment of industrial effluent on water quality of the receiving. Alaro River, in Ibadan, Nigeria; 2005.

7. Gebrekidan M, Samuel Z. Concentration of heavy metals in drinking water from urban areas of the Tigray region, Northern Ethiopia. Momona Ethiopian Journal of Science. 2011;3(1):105-121.

8. Onwughara N, Ajiwe V, Nnabuenyi H. Physicochemical Studies of Water from Selected Boreholes in Umuahia North Local Government Area, in Abia State, Nigeria. International Journal of Pure and Applied Bioscience. 2013;1(3):34-44.

9. Ferezer Eshetu Tegegn. Physico-chemical pollution pattern in Akaki river basin, addis Ababa, Ethiopia. Stockholm University; 2012. p. 1-38.

10. Tamiru A, Dagnachew L, Tenalem A. Hydrology, Water Quality and the Degree of Ground Water Vulnerability to Pollution in Addis Ababa, Ethiopia. Addis Ababa: UNEP/UNESCO/UN HABTATE /ECA; 2005.

11. WHO. Guidelines for Drinking Water Quality: Recommendations. 3rd edition. Geneva: World Health Organization; 2008;1:515.

12. Kaizer A, Osakwe S. Physicochemical characteristics and heavy metal levels in water samples from five river systems in Delta State, Nigeria. Journal of Application of science and Environmental management. 2010;14(1):83-87.

13. Arruti A, Fernández-Olmo I, Irabien A. Evaluation of the contribution of local sources to trace metals levels in urban PM2.5 and PM10 in the Cantabria region (Northern Spain). J Environ Monit. 2010;12(7):14511458.

14. Kanu I, Achi OK. Industrial effluents and their impact on water quality of receiving rivers in Nigeria. Journal of Applied technology in Environmental Sanitation. 2011;1(1):75-86.

15. Agarwal A, Manish S. Assessment of Pollution by Physicochemical Water Parameters Using Regression Analysis: A Case Study of Gagan River at Moradabad- India. Advances in Applied Science Research. 2011;2(2):185-189.

16. Smol J. Pollution of Lakes and Rivers: A Paleo Environmental Perspective. New York: Oxford University Press Inc; 2002.

17. EEPA. Guideline Ambient Environmental Standards for Ethiopian. Prepared by Ethiopian Environmental Protection Authority in collaboration with the United Nation Industrial Development Organization, Addis Ababa; 2003. 
18. Swisher R. Surfactants: from recalcitrant to docile. Proc. Internationa Degradation Symposium. In: Shapely JM, Kaplan AM, editors. 1975. p. $853-886$

19. Belanger S, Lee D, Bowling J, et al. Responses of periphyton and invertebrates of a tetradecyl-pentadecyl sulfate mixture in stream mesocosms. Environmental Toxicology and Chemistry. 2004;23(9):22022213

20. El-gohary FA, Abo-Elela SI, Ali HA. Management of waste water from soap and food industries: A case study. Sci Total environ. 1987;66:203212 .

21. Kanu I, Achi OK, Ezeronye OU, et al. Seasonal variation in bacterial heavy metals bio sorption in water sample from Ezaima River near Soap and Brewery industries and the environmental healthimplication. Int $J$ Environ Sci Tech. 2006;3(1):95-102.

22. Tulonen T, Philstrom M, Arvola L, et al. Concentration of Heavy Metals in Food Web components of Small Boreal Lake. Boreal Environ Res. 2006;11:185-194.

23. USEPA. U.S. Environmental Protection Agency, American Society of Civil Engineers, and American Water Works Association Technology Transfer Handbook: Management of Water Treatment Plan Residuals. EPA/625/R-95/008. Washington DC; 1999.

24. Karr D, Sur P, Mandal S, et al. Assessment of heavy metal pollution in surface water. Int J Environ Sci Tech. 2008;5(1):119-124.

25. Abdullahi M. Toxic effects of lead in humans: an overview. Global Advanced Journal. 2013;2(6):157-162.

26. Weiner E. Applications of Environmental Aquatic Chemistry: A Practical Guide. 2nd edition. United States of America: Taylor and Francis Group, LLC; 2008.

27. Gupta D, Sunita, Saharan J. Physicochemical analysis of Ground water of selected Area of Kaithal city (Haryana) India. Researcher. 2009;1(2):1-5.

28. Amina S. Assessment of Water Quality in Rivers and lakes with respect to heavy metals general water quality parameters: A review. Departments of chemistry. Northwest University Keno, Nigeria. Application of Science and Environmental Management. 2015;414(1):83-87.

29. WHO. Water for Pharmaceutical Uses. In: Quality Assurance of Pharmaceuticals: A Compendium of Guidelines and Related Materials. 2nd Updated edn. Geneva: World Health Organization; 2006. 2:170-171.

30. Malik D, Singh S, Thakur J, et al. Heavy metal pollution of Yamuna River: An Introspection. International journal of current microbiology and Applied Sciences. 2014;3(10):856-863.

31. Olatunji OS, Osibanjo O. Determination of Selected Heavy Metals in Inland Fresh Water of Lower River Niger drainage in North Central Nigeria. African Journal of Environmental Science and Technology. 2012:6(10)

32. Adewoye SO. Effects of detergents effluent discharges on the aspect of water quality of ASA River, llorrin, Nigeria. Agric Biol J $\mathrm{N} \mathrm{Am}$. 2010;1(4):731-736

33. Abdulmimin A, Abubakar IT, Magaji L. A review on Industrial effluents as a major sources of Water Pollution in nigeria. Chemistry journal. 2015;(5):159-164.

34. WTAMO. Woliso Town administrative Mayer office. 2014.

35. WTWSO. Woliso Town water and Sewerage office. 2014.

36. Maiti SK. Hand books of Methods in Environmental Studies. $2^{\text {nd }}$ ed. Water and Waste Water Analysis. India: ABD publishers; 2004:1.
37. South Dakota State Department of Environmental and Natural Resources Water Resources Assistance Program. Standard operating procedure for field samplers. 2005;1:10-40.

38. APHA. Standard methods for the examination of water and wastewater Washington DC, USA: American Public Health Association; 1999.

39. DR 2008 Spectrophotometer. Procedural manual. 2nd ed; 2007.

40. Theodore D. Determination of trace elements in drinking water by axially viewed inductively coupled plasma-atomic emission spectrometer. National Exposure Research laboratory office of Research and development U.S. Environmental Protection Agency, 2003.

41. Zinabu GM, Pearce GN. Concentration of heavy metals and related trace elements in Ethiopian Rifty-Valley Lakes and them in-flows. Hydrobiologia.2003;429:171-178.

42. Ahipathy M, Puttaiah E. Ecological Characteristics of Vrishabhavathi River in Bangalore, India. Environmental Geology. 2006;49(8):12171222 .

43. Wondimu L, Tesso M. Assessment of Water Quality of Hulluka and Alaltu Rivers of Ambo, Ethiopia. J Agr Sci Tech. 2011;13:131-138.

44. Seyoum Leta, Fassil Assefa, Dalhammer G. Characterization of tannery wastewater and assessment of downstream pollution profiles along Modjo River in Ethiopia. Ethiop J Bio Sci. 2003;2:157-168.

45. Getachew Beneberu. The Family chironomidae (Insecta:Diptera) as indicator of environmental stress, and micro-invertebrate based on multimetric index developmentin some selected rivers in Ethiopia. Ph.D Dissertation, School of Graduate studies Addis Ababa University; 2013.

46. Orebiyi E, Awomeso J, Idowu O, et al. Assessment of pollution hazards of shallow well water in Abeokuta and environs, southwest, Nigeria. American journal of environmental science. 2010;6(1):50-56.

47. London L, Dalvie M, Nowicki A, et al. Approach for regulating water in south Africa for presence of pesticides. Water SA. 2005;31(1):53-60.

48. Admasu Tassaw. Assessment of Biological integrity using physicochemical parameters and Macroinvertebrate community index. M.Sc. Thesis, school of Graduate Studies, Addis Ababa University; 2007.

49. Fassil Dagefu, Aschalew Lakaw, Yared Tigabu, et al. The water Quality Degradation of Upper Awash river, Ethiopia. Journal of Environmental studies and Management. 2013;6(1).

50. Ikomi R, Ojieh C. Some Aspect of the biology of aphyosemion gardneri (PISCES: CYPRIODONTIDAE) in river Ethiope, Niger Delta, Nigeria. $J$ Bioscience Research. 1997;9(3):173-181.

51. ReVelle P, Charles R. The Environment: Issues and Choices for Society. Boston: Jones and Bartlett Publishers; 1988.

52. SAEPA. The disposal of soaps and detergents. Government of South Australia Environmental stress and macro invertebrate based on multimetric index development. EPA 547/04. 2004.

53. Ja'afar R. Heavy metals pollution on surface water sources in Kaduna Metropolis, Nigeria. Science World Journal. 2015;10(2).

54. Rajappa B, Manjappa S, Puttaiah E. Monitoring of heavy metal concentration in ground water of Hakinaka Taluk, India. Cotemporary engineering sciences. 2010;3(4):183-190. 